\title{
Prehistoric exploitation of minerals resources. Experimentation and use-wear analysis of grooved stone tools from Grotta della Monaca (Calabria, Italy)
}

\author{
Isabella Caricola ${ }^{1,2}$ (1) - Francesco Breglia ${ }^{2,3} \cdot$ Felice Larocca ${ }^{2,4} \cdot$ Caroline Hamon $^{5}$ - Cristina Lemorini ${ }^{6}$. \\ François Giligny ${ }^{2,4}$
}

Received: 24 June 2020 / Accepted: 2 October 2020 / Published online: 19 October 2020

(C) The Author(s) 2020

\begin{abstract}
The Calabria region of Southern Italy is rich in mineralisation. Unfortunately, no consistent data are available about mineral exploitation in the later prehistoric periods. The Grotta della Monaca mine in Calabria is a prehistoric site that is characterised by the mineralisation of iron ores (such as goethite) and copper carbonates (malachite and azurite). For this reason, the site provides an exceptional opportunity to study a prehistoric mine in which several minerals were exploited during the late Neolithic and early Chalcolithic. In this study, we present the results of an experimental protocol and use-wear analysis conducted using macrolithic tool replicas to extract mineral resources. The experimental test aimed at reconstructing the function of grooved stone tools found at Grotta della Monaca. Use-wear observation, through a combined low- and high-power approach on experimental and archaeological objects, allowed us to define different extraction techniques and methods of mineral treatments. These data enhance our understanding and reconstruction of the chaine opératoires, economic choices, and cultural aspects that characterised prehistoric miners in Southern Italy.
\end{abstract}

Keywords Grooved stone tools $\cdot$ Use-wear $\cdot$ Experimental archaeology $\cdot$ Prehistoric mines $\cdot$ Minerals $\cdot$ Italy

\section{Introduction}

The study of prehistoric mining practices can enhance our understanding of ancient communities' socio-economic and

Electronic supplementary material The online version of this article (https://doi.org/10.1007/s12520-020-01219-7) contains supplementary material, which is available to authorized users.

Isabella Caricola

isabella.caricola@newcastle.ac.uk

1 School of History, Classics and Archaeology, Newcastle University, Newcastle, UK

2 Centro Regionale di Speleologia “Enzo dei Medici”, Via Lucania, 3, 87070 Roseto Capo Spulico, CS, Italy

3 Cultural Heritage Science, Salento University, Lecce, Italy

4 Aldo Moro, Gruppo di ricerca speleo-archeologica, Bari University, Piazza Umberto I, 1, 70121 Bari, Italy

5 Paris1-Panthèon Sorbonne University, UMR 8215 - Trajectories, Paris, France

6 Department of Classics, Sapienza University, Rome, Italy cultural complexity and organisation. Indeed, prehistoric exploration of mineral resources can be related to increasing demand for raw materials by ancient human groups (Binder et al. 2013). The exploitation of minerals produces a series of collateral activities, such as exchanges, contacts between populations, and the development of specific technical skills necessary for the exploitation of the mineral resources. Techno-economy models (Binder et al. 2013; Stöllner 2003) can help illuminate behaviours related to prehistoric social activities, including mining dynamics. Through their technical choices, individuals express their intention. For this reason, the succession of actions is simultaneously the result of technical, social, and cultural choices (Lemonnier 1992, 2010; Pfaffenberger 1998).

In recent years, few methodological studies dedicated to understanding the dynamics of mineral exploitation during prehistory are known. Technological and functional analysis conducted on macro-lithic tools such as ground stone tools, percussion tools (e.g., hammers, picks, and hammer-axes), anvils, crushing tools, and abraders found near and/or in mines has contributed to the identification and understanding of mining activities (Breglia et al. 2016; Caricola and Lemorini 2017; Delgado-Raack et al. 2014; Hamon 2016; Hamon 
2008; Delgado-Raack and Gómez-Gras 2017; GromanYaroslavski et al. 2016; Rafel et al. 2016).

Experimental archaeology has allowed researchers to test different mining techniques (Craddock 1990; Lewis 1990; Timberlake 1990) and compare with ethnographic evidence (Crew 1990; Eerkens et al. 2009; Timberlake 1990).

An in-depth reconstruction of chaine opératoires has been carried out primarily on European flint mines (Babel 1986; Charraud et al. 2014; Collet et al. 2016; Felder 1981; Galiberti 2005; Migal 1997; Tarriño et al. 2014), where several studies have been conducted to test resource exploitation models and identify all the stages, from extraction to the production of pre-forms (Di Lernia and Galiberti 1993). These analyses reveal the complexity of the economic and social organisation of prehistoric mining groups. However, flint was not the exclusive natural resource exploited during prehistory. Extraction evidence exists for hyaline quartz (Rostan and Thirault 2016), jasper Campana et al. 2014a, b; Negrino and Starnini 2010; Scaramucci et al. 2016), salt (Bànffy 2015; Hamon 2016; Harding 2013; Olivier and Kovacik 2006), variscite (Camprubi et al. 2003), and cinnabar (Cavanna and Pellegrini 2007; Poggiali et al. 2017).

In the literature, several mines of hydroxides and oxides are attested in prehistoric Europe (Levato 2013), exploited between the Palaeolithic and Neolithic (Dobosi 2006; Goldenberg et al. 2003; Koukouli-Chrysanthaki and Weisgerber 1999). The oldest copper mines in Europe (e.g., Rudna Glava, Serbia) have been exploited since the late Neolithic (Boric 2009; Jovanović 1979; O’Brien 2014) and throughout the Chalcolithic and the Bronze Age (Ambert 1995, 1996, 2002; Ambert et al. 2005; Angelini et al. 2013; Bouquet et al. 2006; Campana et al. 2006; Cortesogno et al. 2004; Cortina 2011; Delgado-Raack et al. 2014; Guendon et al. 2008; Laroche et al. 2011; Maggi and Del Lucchese 1988; Maggi and Pearce 2005, 2014; O'Brien 1997; 2014; Preuschen 1973; Rafel et al. 2016). The prehistoric European copper and iron ore mines feature extraction technologies that change by resource type. The literature has identified extractive lithic tools made of different raw materials, morphologies, production techniques, and handling modes (Campos et al. 2007; Cortesogno et al. 2004; Cortina 2011; De Pascale 2004; Gale 1990; Goldenberg et al. 2003; Rafel et al. 2016). Tools from hard animal materials are also attested (Campos et al. 2007; Černych 1978; O’Brien 2014). Specific toolkits are necessary to excavate pits and galleries and extract minerals. The latter is not a simple and direct action. It requires a specific chaine opératoires, adopting a set of techniques that allow the systematic exploitation of minerals.

In this paper, we focus on the prehistoric mine Grotta della Monaca in Calabria, Italy, where evidence of iron ore and copper carbonate exploitation was found (Larocca 2005).

We formulate hypotheses concerning the extraction techniques used in this mine, as supported by experimental activity and a detailed analysis of the use-wear traces found on well-preserved stone artefacts. The site represents the oldest (chronological range c. 4080-3920/3540-3660 BC) and only known extractive context of the Calabria region, a geographical area still unknown archaeologically, which requires further investigations. Therefore, the following imperative research questions arise: (1) What was the role of the Calabria region in the exploitation, use, and diffusion of mineral resources? (2) Which minerals resources were exploited and for what purposes? What technologies were used? Nothing is known about these early crucial changes, and currently, there are no contexts comparable with Grotta della Monaca in Italy. For these reasons, this study would be a valuable contribution for the reconstruction of economic and cultural dynamics affecting the final Neolithic and early Copper Age in Southern Italy.

\section{The archaeological context}

Grotta della Monaca is a karstic cave located in Sant'Agata di Esaro in north-western Calabria at $650 \mathrm{~m}$ asl, near the Esaro River (Fig.1). The cave develops for $360 \mathrm{~m}$ and revealed a wide chronological range of human occupation, dating from the Upper Palaeolithic (Quarta et al. 2013) to post-medieval periods (16th-18th centuries AD) (Larocca 2012; Levato and Larocca 2015).

This continuity is due, in part, to the presence of massive minerals outcrops. The preponderant iron ores present include goethite $[\alpha \mathrm{FeO}(\mathrm{OH})]$, which can be associated with lepidocrocite $[\gamma \mathrm{FeO}(\mathrm{OH})]$, a polymorph of goethite; haematite $[\alpha \mathrm{Fe} 2 \mathrm{O} 3]$; and yukonite $[\mathrm{Ca} 2 \mathrm{Fe} 3(\mathrm{AsO} 4) 4(\mathrm{OH})$. $12 \mathrm{H} 2 \mathrm{O}]$, a hydrated arsenate of iron and calcium (Garavelli et al. 2009; Levato and Larocca 2015). Additionally, copper carbonates, malachite [Cu2 $(\mathrm{CO} 3)(\mathrm{OH}) 2]$, and azurite $[\mathrm{Cu} 3(\mathrm{CO} 3) 2(\mathrm{OH}) 2]$ are present in the inner part of the mine. These mineralisations are often associated with copper sulphates and phosphates, such as brochantite [ $\mathrm{Cu} 4$ $(\mathrm{SO} 4)(\mathrm{OH}) 6]$, libethenite $[\mathrm{Cu} 2(\mathrm{PO} 4)(\mathrm{OH})]$, and sampleite $[\mathrm{NaCaCu} 5(\mathrm{PO} 4) 4 \mathrm{Cl} \cdot 5 \mathrm{H} 2 \mathrm{O}]$ (Dimuccio et al. 2005; Dimuccio et al. 2017; Levato and Larocca 2015).

Grotta della Monaca is conventionally divided into three areas: (1) the entrance gallery, which is called Pregrotta; (2) a second large and dark room, called Sala dei Pipistrelli; and (3) two narrow tunnels called Cunicoli Terminali (Larocca 2005). The minerals are localised differently. Iron ores are found throughout the cave, while copper ores are concentrated at the end of the cave in the Cunicoli Terminali area.

The archaeological excavations conducted from 2002 until 2010 allowed us to identify the extraction areas. In particular, a sub-horizontal passage called "Buca delle impronte" that is located in the inner part of the Sala dei Pipistrelli yielded relevant archaeological evidence of mineral exploitation. This passage is $11 \mathrm{~m}$ long and 

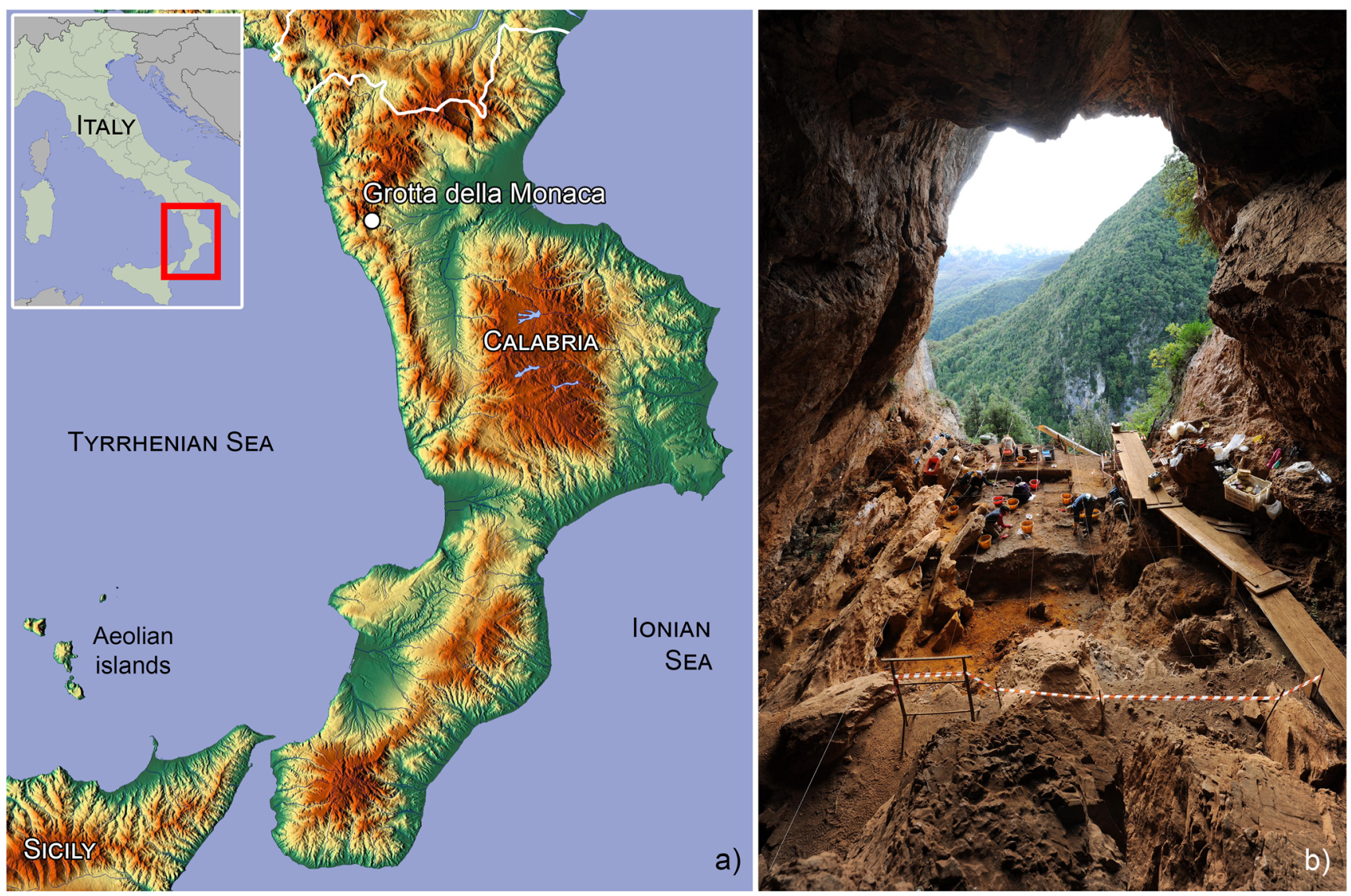

GROTTA DELLA MONACA - PLANIMETRY

Buca delle Impronte

c)

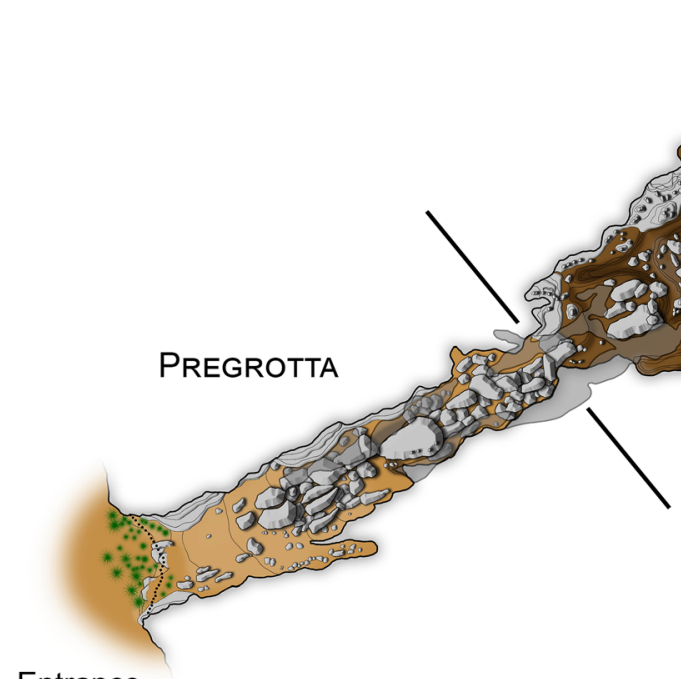

Ramo delle Vaschette

Ramo delle vaschette
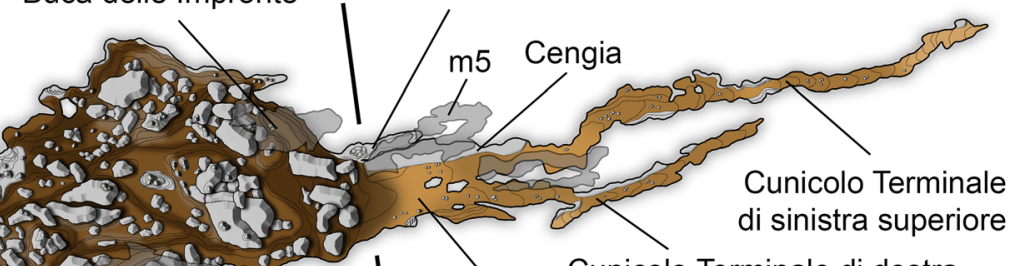

di sinistra superiore

Vestibolo

Cunicolo Terminale di destra

CUNICOLI TERMINALI

Sala dei Pipistrelli

\section{Entrance}

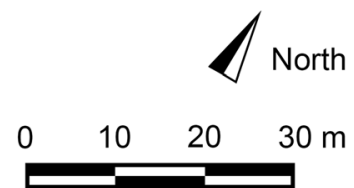

Fig. 1 Grotta della Monaca mine (Calabria, Italy). a Geographic map. b The entrance to the mine. $\mathbf{c}$ Planimetry of the cave (the images were made and processed by F. Breglia and F. Larocca)

between $60 \mathrm{~cm}$ to $4 \mathrm{~m}$ wide (Levato and Larocca 2015). Inside this conduit, well-preserved traces of digging have been found. These imprints on soft goethite veins have been interpreted as traces of deer antlers, animal scapulae, and other unidentifiable tools probably in animal matter.
Not flakes of stone tools were found (Levato and Larocca 2015). Radiocarbon dates obtained from charcoal samples of remains of wooden torches of Pinus sylvestris allow the assignment of this exploitation phase to the final Neolithic, between 3800 and $3640 \mathrm{BC}$ and 3780-3630 BC (Larocca 
2010; Larocca 2012; Levato and Larocca 2015; Quarta et al. 2013) (Table 1).

The excavations carried out in the Cunicoli Terminali highlighted the presence of several other mining areas (Cengia, Ramo delle Vaschette, and right- and left-Cunicoli Terminali), closely related to the outcrops of copper carbonates. Here, several remains of extractive lithic tools have been found intact and associated with flakes as well. The radiocarbon dating assigns these mining activities to a period between the late Neolithic and early Copper Age (Larocca 2012; Levato and Larocca 2015, Quarta et al. 2013) and identify the cave as the oldest known copper mine in Italy. The transition from the Neolithic to the Chalcolithic age is characterised by the
Spatarella facies, followed by the introduction of the Piano Conte pottery, widespread in the Aeolian Archipelago and in various peninsular contexts, including the Tyrrhenian coast of Calabria Region (Cazzella et al. 2011; Salerno and Vanzetti 2004). To date, however, the scarcity of extensive excavations in the Calabria Region makes it difficult to delineate an organic picture, especially for the Copper Age (Genik 2008). In southern Italy, the cultural relationships and chronological links between the different facies of the Copper Age are still only approximately perceived (Pacciarelli and Talamo 2011).

Grotta della Monaca lies along a low-altitude pass (Passo dello Scalone) that could have favoured and promoted contacts between coastal and inner areas. Such contacts and
Table 1 Radiocarbon dating from Prehistoric mining areas excavated at Grotta della Monaca

\begin{tabular}{|c|c|c|c|}
\hline Context & ID sample & Radiocarbon Dating & Reference \\
\hline US1-Ramo delle Vaschette & $\begin{array}{l}\text { LTL3583A } \\
\text { Charcoal } \\
\text { Pinus } \\
\quad \text { sylvestris }\end{array}$ & $\begin{array}{l}5183 \pm 50 \mathrm{BP} \\
4230-4200 \mathrm{cal} .2 \sigma \mathrm{BC} \\
\quad(2.3 \%) ; \\
4170-4090 \mathrm{cal} .2 \sigma \mathrm{BC} \\
\quad(4.9 \%) ; \\
4080-3920 \mathrm{cal} .2 \sigma \mathrm{BC} \\
\quad(79.4 \%) ; \\
3880-3800 \mathrm{cal} .2 \sigma \mathrm{BC} \\
\quad(8.9 \%)\end{array}$ & $\begin{array}{l}\text { Larocca 2012; Quarta et al. } \\
\quad 2013\end{array}$ \\
\hline $\begin{array}{l}\text { US1-Ramo delle Vaschette, } \\
\text { carbone }\end{array}$ & $\begin{array}{l}\text { LTL3584A } \\
\text { Charcoal } \\
\text { Pinus } \\
\quad \text { sylvestris }\end{array}$ & $\begin{array}{l}5010 \pm 50 \mathrm{BP} \\
3950-3690 \text { cal. } 2 \sigma \mathrm{BC} \\
\quad(95.4 \%)\end{array}$ & $\begin{array}{l}\text { Larocca 2012; Quarta et al. } \\
\quad 2013\end{array}$ \\
\hline Cengia & $\begin{array}{l}\text { LTL5092A } \\
\text { Charcoal } \\
\text { Pinus } \\
\quad \text { sylvestris }\end{array}$ & $\begin{array}{l}5216 \pm 45 \mathrm{BP} \\
4170-3950 \mathrm{BC}(89,6 \%)\end{array}$ & Quarta et al. 2013 \\
\hline Cengia & $\begin{array}{l}\text { LTL5093A } \\
\text { Charcoal } \\
\text { Pinus } \\
\quad \text { sylvestris }\end{array}$ & $\begin{array}{l}5194 \pm 45 \text { BP } \\
4080-3940 \text { BC }(85,2 \%)\end{array}$ & Quarta et al. 2013 \\
\hline $\begin{array}{l}\text { Cunicolo Terminale di } \\
\text { Sinistra Superiore }\end{array}$ & $\begin{array}{l}\text { LTL5395A } \\
\text { Charcoal } \\
\text { Pinus } \\
\quad \text { sylvestris }\end{array}$ & $\begin{array}{l}5247 \pm 45 \text { BP } \\
4180-3960 \text { BC cal. } 2 \sigma \\
\quad(95.4 \%)\end{array}$ & Quarta et al. 2013 \\
\hline $\begin{array}{l}\text { Cunicolo Terminale di } \\
\text { Sinistra Superiore }\end{array}$ & $\begin{array}{l}\text { L3579A } \\
\text { Goat Horn }\end{array}$ & $\begin{array}{l}4684 \pm 50 \mathrm{BP} \\
3640-3560 \mathrm{BC} \text { cal. } 2 \sigma \\
\text { BC }(17.1 \%), \\
3540-3660 \mathrm{cal} .2 \sigma \mathrm{BC} \\
\quad(78.3 \%)\end{array}$ & $\begin{array}{l}\text { Quarta et al. 2013; Levato and } \\
\text { Larocca } 2015\end{array}$ \\
\hline Buca delle Impronte & $\begin{array}{l}\text { LTL-3581A } \\
\text { Charcoal } \\
\text { Pinus } \\
\quad \text { sylvestris }\end{array}$ & $\begin{array}{l}4880 \pm 45 \mathrm{BP} \\
3780-3630 \mathrm{BC}(89.8 \%) ; \\
3580-3530 \mathrm{BC} \\
(5.6 \%)\end{array}$ & $\begin{array}{l}\text { Levato and Larocca 2015; } \\
\text { Larocca 2010; Quarta et al. } \\
\quad 2013\end{array}$ \\
\hline Buca delle Impronte & $\begin{array}{l}\text { LTL-3582A } \\
\text { Charcoal } \\
\text { Pinus } \\
\quad \text { sylvestris }\end{array}$ & $\begin{array}{l}4935 \pm 45 \mathrm{BP} \\
3800-3640 \mathrm{BC}(95.4 \%)\end{array}$ & $\begin{array}{l}\text { Levato and Larocca 2015; } \\
\text { Larocca 2012; Quarta et al. } \\
\quad 2013\end{array}$ \\
\hline
\end{tabular}


exchange activities are attested by exogenous elements such as obsidian imports from the Aeolian Archipelago during Neolithic and Copper Age (Acquafredda et al. 2016; Acquafredda et al. 2020).

Currently, studies of the pottery from the cave are in progress. These data will provide additional information on the cultural aspects of the groups of miners of Grotta della Monaca. Unfortunately, the interpretation of these aspects is hindered due to medieval mining activities, including excavations in the Pregrotta. The latter represents the area where the prehistoric miners probably stayed and large quantities of ceramics, ground stone tools and abraders have been found as well (Breglia et al. 2016). The ground stone tools show usewear connected with the treatment of the goethite, while the abraders present traces related to a contact with stone and leather. They are objects connected with the miners and characterise the Pregrotta as a mineral processing area (Breglia et al. 2016; Caricola and Lemorini 2017).

\section{Materials and methods}

\section{The archaeological samples}

In this paper, we present the results of the use-wear analyses conducted on 25 well-preserved grooved stone tools found in Grotta della Monaca. At the Pregrotta area, grinding tools, grinders/crushers, and abraders have been found (Breglia
Fig. 2 Archaeological samples of grooved stone tools found in Grotta della Monaca mine. Hammers and fragmentary tools
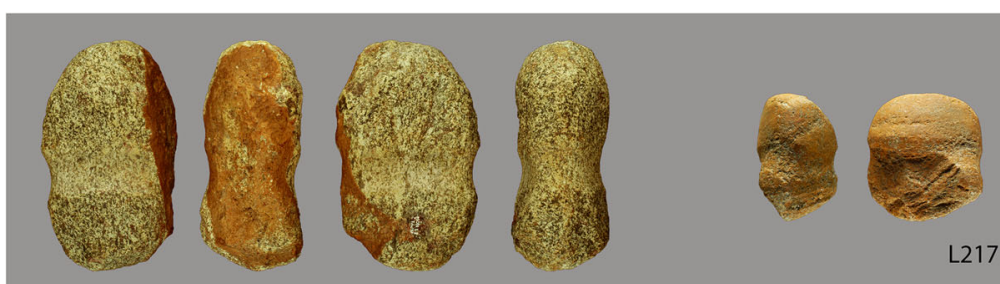

L8
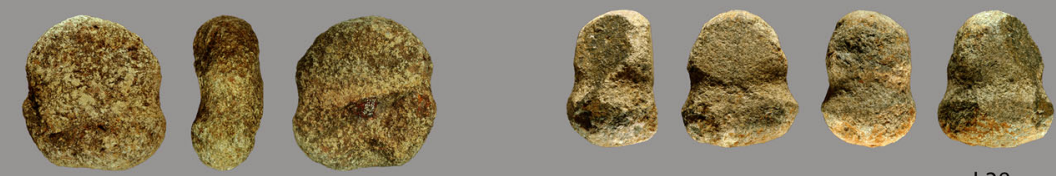

L6

L38
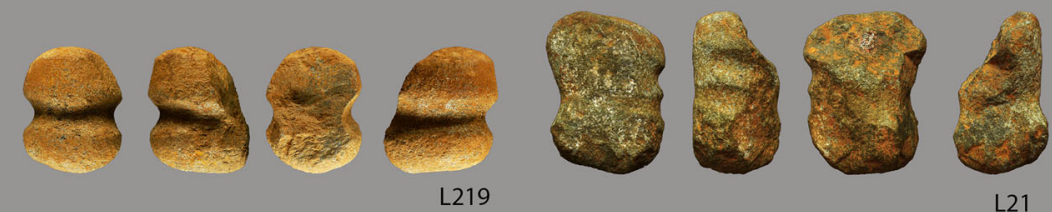

L21
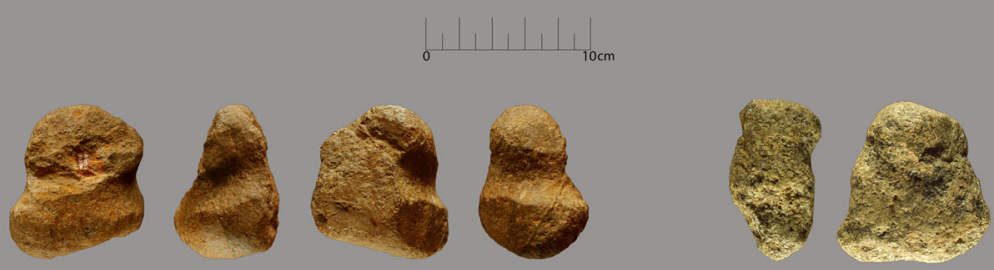

$\mathrm{L} 2$

L19
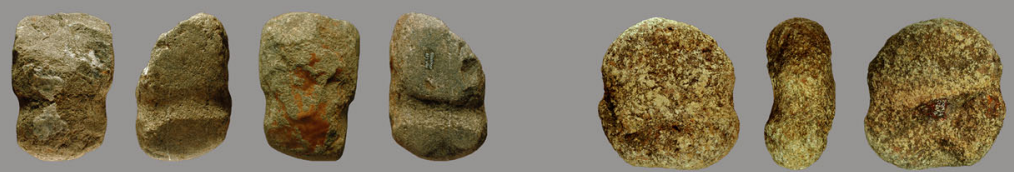

L37
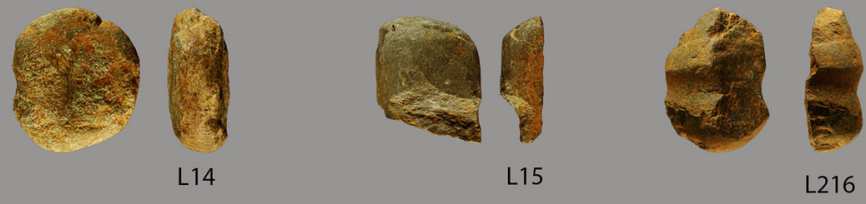
et al. 2016) along with one extractive tool, completely covered by goethite concretions; in the terminal area of the cave, Sala dei Pipistrelli and Cunicoli Terminali, hammers (characterised by two flat ends) (Fig. 2), hammer-axes (consisting of a trenchant opposite to a flat end), and picks (with a pointed end) (Fig. 3), usually characterised by a median grooved and/or notches that were useful for handles, have been found. In addition, numerous flakes and fragments of grooved stone tools have been found in this area (see supplementary materials Fig. 1). The entire collection is composed of 71 mining tools, including intact or semi-intact tools with determinable morphology $(n=22)$, fragments of different sizes $(n=20)$, and flakes $(n=29)$ (Breglia et al. 2016). Only 25 tools $(n=20$ intact and $n=5$ fragments with well-preserved functional surfaces) have been selected for this study's usewear analysis. All the selected artefacts come from the inner
Fig. 3 Archaeological samples of grooved stone tools found in Grotta della Monaca mine. Hammer-axes and picks

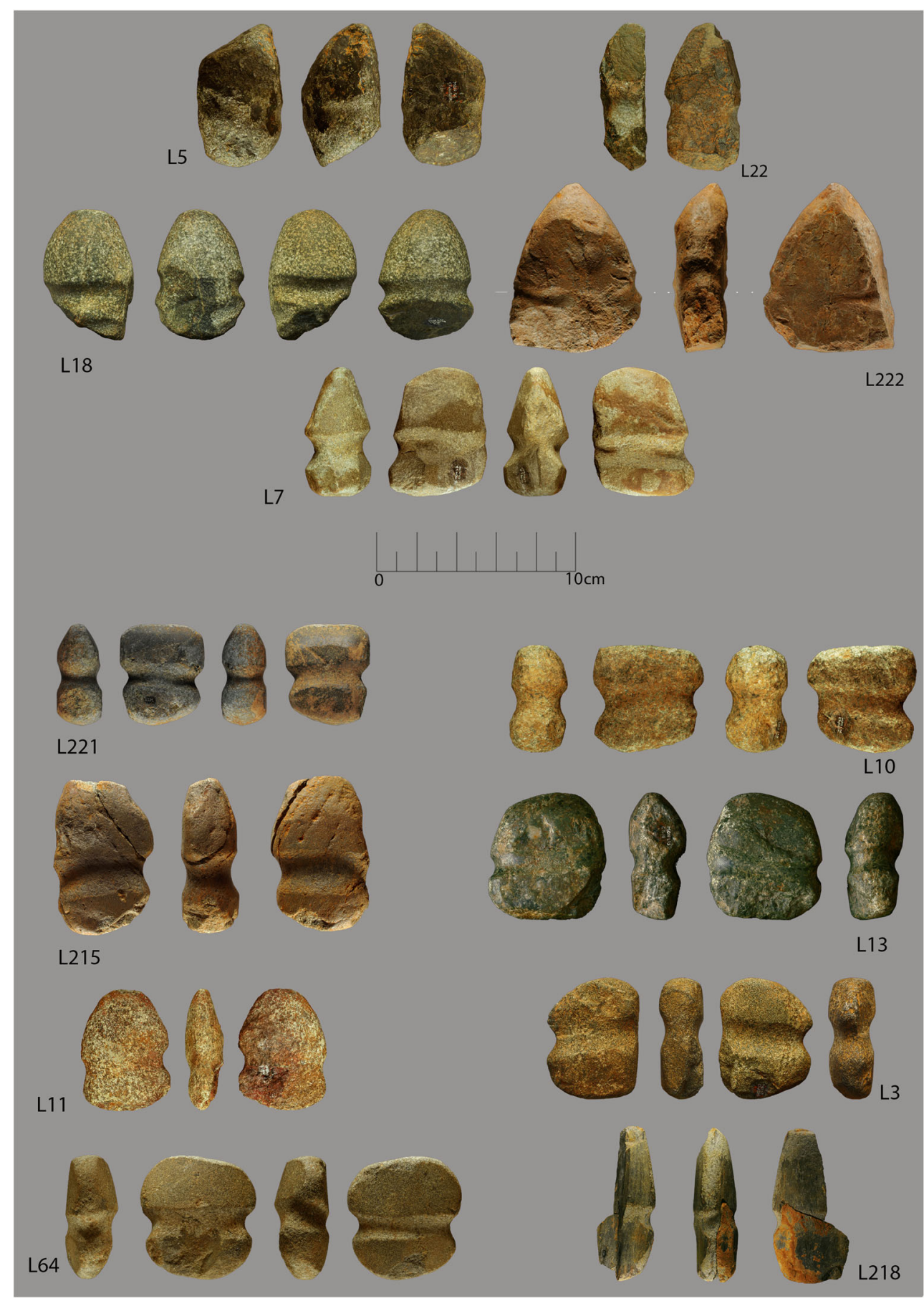


Table 2 Archaeological samples analysed: tool types, raw materials determination, size, and state of preservation. The samples come from the left (sx) and the right (dx) side of the Cuniculi Terminali (CT) area, Vestibolo dei Cuniculi Terminali (CTv), rV (Ramo delle Vaschette), m5 (sector of the CTv)

\begin{tabular}{|c|c|c|c|c|c|c|c|c|c|c|c|}
\hline ID & Type of tool & $\begin{array}{l}\text { Raw } \\
\text { material }\end{array}$ & Area of discovery & $\begin{array}{l}\mathrm{L} . \\
\mathrm{mm}\end{array}$ & $\begin{array}{l}\text { Wi. } \\
\mathrm{mm}\end{array}$ & $\begin{array}{l}\mathrm{T} . \\
\mathrm{mm}\end{array}$ & $\begin{array}{l}\text { We. } \\
\text { g }\end{array}$ & Groove & Notches & $\begin{array}{l}\text { Production } \\
\text { Technique }\end{array}$ & Preser. \\
\hline L11 & Hammer-axe & Metagabbro & $\mathrm{MON} / \mathrm{CTV}$ & 115 & 81 & 31 & 610 & $\checkmark$ & - & Pits + Abrasion & Intact \\
\hline L21 & Hammer & Ophiolite & $\mathrm{MON} / \mathrm{CTV} / \mathrm{m} 5$ & 139 & 99 & 70 & 1439 & - & $\checkmark$ & Pits & Intact \\
\hline L22 & Pick & Kinzigiti & MON/CTsx & 153 & 77 & 46 & 973 & - & $\checkmark$ & Pits & Intact \\
\hline L15 & Undefined & Ophiolite & $\mathrm{MON} / \mathrm{CTV} / \mathrm{rV}$ & 104 & 88 & 35 & 714 & - & - & $\mathrm{Nd}$ & Fragm. \\
\hline L8 & Hammer & Metagabbro & MON/CTdx & 180 & 95 & 61 & 3112 & $\checkmark$ & - & Pits+Abrasion & Intact \\
\hline L13 & Hammer-axe & Ophiolite & $\mathrm{MON} / \mathrm{CTV}$ & 101 & 91 & 40 & 874 & $\checkmark$ & - & Pits + Abrasion & Intact \\
\hline L217 & Hammer & Metagabbro & MON/CTdx & 94 & 85 & 59 & 780 & $\checkmark$ & - & Pits+Abrasion & Intact \\
\hline L7 & Hammer-axe & Amphibolite & MON/CTdx & 130 & 94 & 60 & 1036 & $\checkmark$ & - & Pits+Abrasion & Intact \\
\hline L10 & Hammer-axe & Kinzigite & $\mathrm{MON} / \mathrm{CTv}$ & 113 & 116 & 62 & 1734 & $\checkmark$ & - & Pits+Abrasion & Intact \\
\hline L222 & Pick & Ophiolite & $\mathrm{MON} / \mathrm{SP}$ & 163 & 139 & 58 & 2047 & $\checkmark$ & $\checkmark$ & Pits+Abrasion & Intact \\
\hline L215 & Hammer-axe & Metagabbro & $\mathrm{MON} / \mathrm{CTv} / \mathrm{m} 5 \mathrm{v}$ & 166 & 93 & 50 & 1584 & $\checkmark$ & - & Pits + Abrasion & Intact \\
\hline L14 & Hammer & Metagabbro & $\mathrm{MON} / \mathrm{CTV} / \mathrm{C} 1$ & 127 & 108 & 50 & 1257 & - & $\checkmark$ & $\begin{array}{l}\text { Concretions on } \\
\text { not-functional } \\
\text { areas }\end{array}$ & Intact \\
\hline L221 & Hammer-axe & Ophiolite & MON/CTdx & 93 & 79 & 41 & 609 & $\checkmark$ & - & Pits+Abrasion & Intact \\
\hline L6 & Hammer & Metagabbro & MON/CTdx & 102 & 91 & 49 & 671 & $\checkmark$ & - & Pits & Intact \\
\hline L3 & Hammer & Amphibolite & $\mathrm{MON} / \mathrm{CTV}$ & 107 & 83 & 40 & 644 & $\checkmark$ & - & Pits + Abrasion & Intact \\
\hline L18 & Pick & Ophiolite & $\mathrm{MON} / \mathrm{CTv} / \mathrm{m} 5$ & 138 & 87 & 84 & 1784 & $\checkmark$ & $\checkmark$ & Pits & Intact \\
\hline L218 & Hammer-axe & Ophiolite & $\begin{array}{l}\text { Fragm.1MON/Ctsx.s/SALTO; } \\
\text { Fragm. } 2 \mathrm{CTV}\end{array}$ & 212 & 98 & 50 & 1044 & $\checkmark$ & - & Pits+Abrasion & $\begin{array}{l}2 \text { fragm. } \\
\text { Recompo- } \\
\text { sed }\end{array}$ \\
\hline L37 & Hammer & Metagabbro & MON/CTdx & 115 & 78 & 70 & 1132 & $\checkmark$ & - & Pits + Abrasion & Intact \\
\hline L38 & Pick-hammer & Metagabbro & $\mathrm{MON} / \mathrm{CTV}$ & 122 & 100 & 80 & 1641 & $\checkmark$ & - & Pits & Intact \\
\hline L64 & Hammer-axe & Amphibolite & MON/CTdx & 122 & 112 & 460 & 1152 & $\checkmark$ & - & Pits + Abrasion & Intact \\
\hline L19 & Hammer & Metagabbro & $\mathrm{MON} / \mathrm{CTv} / \mathrm{m} 5$ & 126 & 111 & 66 & 1391 & $\checkmark$ & $\checkmark$ & Pits & Intact \\
\hline L219 & Hammer & Metagabbro & MON/CTdx & 84 & 65 & 64 & 628 & $\checkmark$ & - & Pits + Abrasion & Intact \\
\hline L216 & Undefined & Ophiolite & MON/CTsx/Salto & 119 & 82 & 42 & 645 & $\checkmark$ & - & Pits+Abrasion & Fragment \\
\hline L5 & Pick & Ophiolite & $\mathrm{MON} / \mathrm{CTv} / \mathrm{m} 5$ & 173 & 90 & 90 & 2248 & $\checkmark$ & - & Pits & Fragment \\
\hline L112 & Undefined & Metagabbro & $\mathrm{MON} / \mathrm{CTV}$ & 112 & 69 & 48 & 539 & $\checkmark$ & - & Pits & Fragment \\
\hline
\end{tabular}

area of the cave (Cunicoli Terminali). Moreover, these tools were not affected by patinas or concretions on the surface.

Petrographic analyses have identified artefacts made of intrusive igneous rocks and a single tool from sedimentary rock (limestone). The other grooved stone tools are made from metamorphic rocks coming from the Sila area of Calabria (Acquafredda and Piccarreta 2005; Breglia et al. 2016) (Table 2). Therefore, these are local rocks collected from alluvial deposits of the main river courses in the area: the Crati and Esaro. These latter cut the various rock formations exposed in the Sila area and transported the debris downstream (Acquafredda and Piccarreta 2005).

The extractive tools were primarily produced using the direct percussion technique, attested by pits to shape the blank and producing grooves and notches. Cobbles were often selected and subsequently modified or, rarely, blocks of angular rocks. All observed tools present pits. In several cases, this technique is associated with an abrasion that is localised into the groove near the functional areas (e.g., trenchant) or covering the entire surface of the object. The average weight per type are hammer-axes around $2.381 \mathrm{~g}$, hammers $1.227 \mathrm{~g}$, and picks $1.738 \mathrm{~g}$ (Table 2).

\section{Methodology}

\section{The use-wear analysis}

The archaeological samples were studied by combining low and high magnification approaches. At low magnification, the specimens were observed utilising a stereo-microscope Nikon SMZ, with progressive magnifications ranging between $\times 10$ and $\times 75 \mathrm{x}$ and Toupview USB camera. At high magnification, a reflectedlight microscope, Nikon Eclipse with a range of magnification from $\times 50$ to $\times 200$, was used. ${ }^{1}$ The experimental samples were

\footnotetext{
${ }^{1}$ At the Laboratory of Technological and Functional Analysis of Prehistoric and Protohistoric Artefacts (LTFAPA) of the Sapienza University of Rome.
} 
observed following the same methodology. The parameters describing the traces were based on the literature about macro(Hamon 2006; Jackson and Hitchiner 2013) and micro-traces (Adams et al. 2009; Caricola et al. 2018; Dubreuil et al. 2015; Van Gijn 2010; Lemorini 2000).

The experimental and archaeological samples were first washed with demineralised water and neutral soap (Derquim $\left.{ }^{\circledR}\right)$. In the case of the experimental samples, several washes to remove the mineral residues were required. All objects were analysed through direct observation; in exceptional cases, silicon molds (Provil Novo Light Fast Heraeus $®$ ) were used to observe the micro-traces under the metallographic microscope.

\section{Experimental framework}

A dedicated experimental reference collection was built in order to interpret the use of the Grotta della Monaca grooved stone tools. The experimental protocol involved the following steps:

- Raw material collection. It was necessary to move from Grotta della Monaca area (Sant'Agata di Esaro, Calabria, Italy) to Malvito (Calabria, Italy; $6.5 \mathrm{~km}$ away) to identify riverbed deposits of large blocks $(70 \times 50 \mathrm{~cm})$ of metamorphic rocks, similar to archaeological finds, near the Esaro River. Moving towards Roggiano Gravina (Calabria, Italy; $15 \mathrm{~km}$ ), widespread deposits of small pebbles and cobbles were collected on the basis of their shape, excluding those on which micro-fractures and cracks, due to weathering, were evident (Fig. 4).

- Tool production. The pebbles were modified in order to produce 19 (for detail see Table 3) replicas, including hammers, hammer-axes, and picks. During this stage, we used hard hammerstones (i.e., in metamorphic

Fig. 4 Experimental phases. a, b Collection of raw materials in the Calabria region (Italy). c, d Production of grooved stone tools and $\mathbf{g}$ production of the ropes in plant fibres $(\mathbf{e}, \mathbf{f})$ and in animal skin (g)

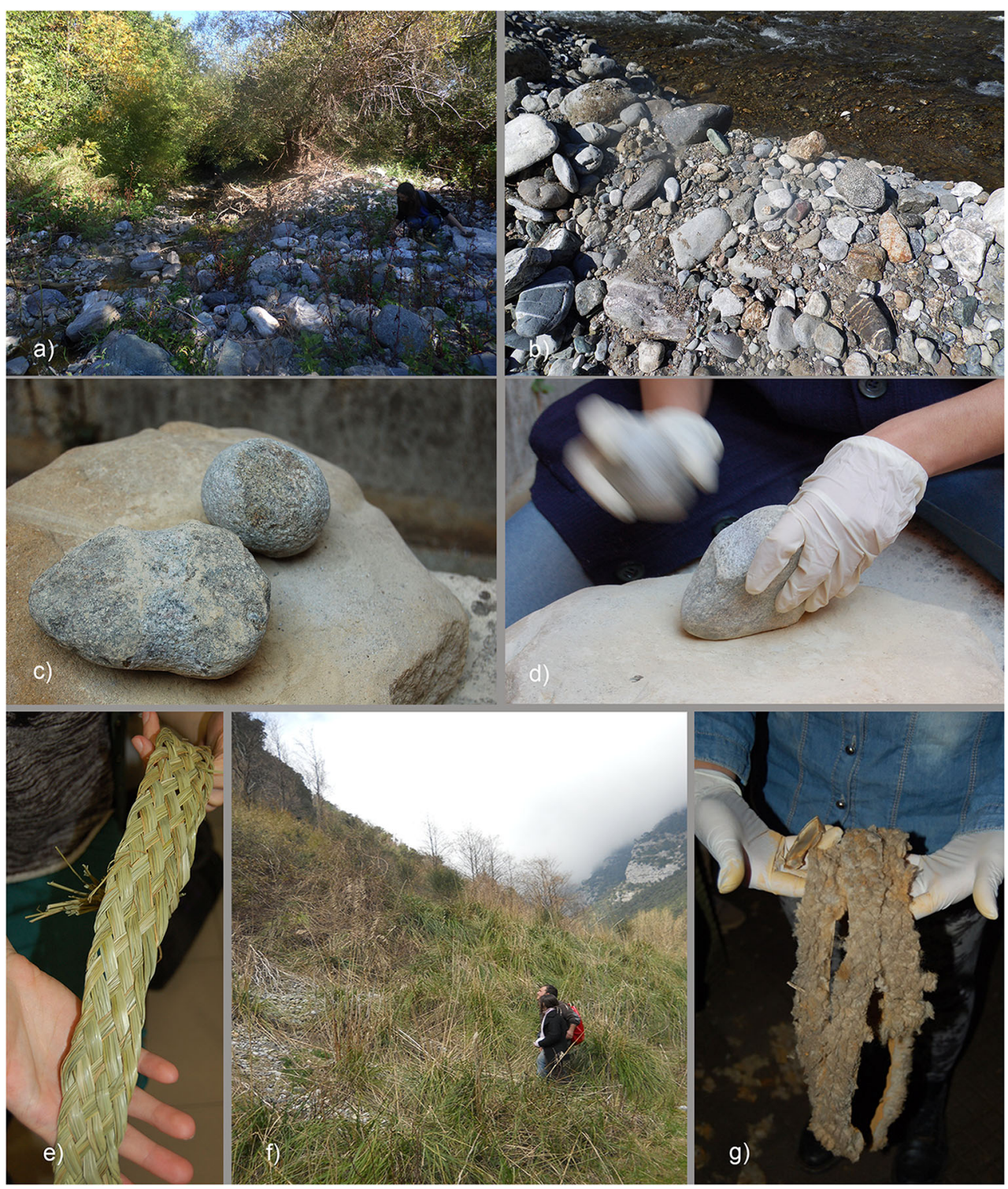


Table 3 Table of experiments. Tool types and extracted minerals; dimensions, duration, and preservations of the samples

\begin{tabular}{|c|c|c|c|c|c|c|c|c|c|}
\hline \multirow{2}{*}{$\begin{array}{l}\text { N. } \\
\text { Exp }\end{array}$} & \multirow{2}{*}{ Type of Tool } & \multirow[t]{2}{*}{ Mineral extraction } & \multirow{2}{*}{$\begin{array}{l}\mathrm{L} . \\
(\mathrm{mm})\end{array}$} & \multirow{2}{*}{$\begin{array}{l}\text { Wi. } \\
(\mathrm{mm})\end{array}$} & \multirow{2}{*}{$\begin{array}{l}\text { T. } \\
(\mathrm{mm})\end{array}$} & \multicolumn{2}{|c|}{ Weight $(\mathrm{g})$} & \multirow[t]{2}{*}{ Duration of use } & \multirow[t]{2}{*}{ Preservation } \\
\hline & & & & & & Before & After & & \\
\hline 1 & Hammer & Copper Carbonates & 104 & 80 & 40 & 889 & 610 & $1 \mathrm{~h} 30 \mathrm{~m}$ & Fracture, 2 longitudinal fragments+micro-flakes \\
\hline 2 & Hammer & Copper carbonates & 90 & 70 & 40 & 580 & 530 & $1 \mathrm{~h} 45 \mathrm{~m}$ & Intact, reduced \\
\hline 3 & Hammer & Soft/hydrated goethite & 110 & 89 & 45 & $/ /$ & 720 & $3 \mathrm{~h} 30 \mathrm{~m}$ & Intact \\
\hline 4 & Hammer & Hard/compact goethite & 111 & 87 & 50 & $/ /$ & 850 & $3 \mathrm{~h}$ & Intact \\
\hline 5 & Hammer & Copper carbonates & 150 & 98 & 60 & 1654 & 1500 & $1 \mathrm{~h}$ & 3 fragments+micro-flakes \\
\hline 6 & Hammer & Copper carbonates & 165 & 100 & 73 & 1850 & 1600 & $1 \mathrm{~h} 15 \mathrm{~m}$ & Fracture, 2 longitudinal fragments+micro-flakes \\
\hline 7 & Pick & Calcite & 170 & 99 & 78 & // & 1700 & $1 \mathrm{~h} 30 \mathrm{~m}$ & Intact \\
\hline 8 & Pick & Mixed deposit & 110 & 85 & 47 & // & 890 & $3 \mathrm{~h}$ & Intact \\
\hline 9 & Hammer-axe & Copper carbonates & 120 & 84 & 46 & 1140 & 1100 & $2 \mathrm{~h}$ & 1 oblique fragment \\
\hline 10 & Hammer-axe & Copper carbonates & 98 & 80 & 39 & 1130 & 715 & $3 \mathrm{~h}$ & 1 oblique fragment+micro-flakes \\
\hline 11 & Hammer-axe & Copper carbonates & 112 & 79 & 47 & 836 & 875 & $3 \mathrm{~h}$ & Intact, reduced \\
\hline 12 & Pick & Calcite & 99 & 82 & 47 & $/ /$ & 780 & $3 \mathrm{~h}$ & Intact \\
\hline 13 & Pick & Copper carbonates & 100 & 80 & 45 & 1120 & 1000 & $3 \mathrm{~h}$ & Intact, reduced \\
\hline 14 & Hammer-axe & Calcite & 80 & 69 & 40 & $/ /$ & 500 & $1 \mathrm{~h} 30 \mathrm{~m}$ & Intact \\
\hline 15 & Hammer-pick & Copper carbonates & 89 & 78 & 48 & 702 & 650 & $2 \mathrm{~h}$ & Intact, reduced \\
\hline 16 & Hammer & Soft/hydrated goethite & 87 & 77 & 47 & $/ /$ & 680 & $1 \mathrm{~h} 30 \mathrm{~m}$ & Intact \\
\hline 17 & Hammer & Mixed deposit & 90 & 79 & 48 & // & 790 & $2 \mathrm{~h}$ & Intact \\
\hline 18 & Pick & Calcite & 80 & 70 & 45 & // & 560 & $2 \mathrm{~h} 10 \mathrm{~m}$ & Intact \\
\hline 19 & Hammer & Hard/compact Goethite & 100 & 90 & 47 & $/ /$ & 800 & $1 \mathrm{~h} 15 \mathrm{~m}$ & Intact \\
\hline
\end{tabular}

rock) to produce grooves or notches by hammering. Soft stones were found to be unsuitable for this type of percussive activity. The abrasion technique was tested as an alternative or in association with the former activities. Consequently, the object's surface became very smooth and polished. The abrasion technique was also used to refine the blank during the final stage (Fig. 4).

- Handle manufacture. Near the cave, different types of wood were selected, including oak (Quercus ilex) and three types of local willow wood (Salix viminalis; Salix caprea; Salix purpurea), based on their flexibility and hardness properties. Different types of handles were produced. The first comprises a length of wood with a Vshaped termination, intended for the insertion of the tool; the second type was created by rolling the flexible wood around the groove. ${ }^{2}$ Additionally, ropes were produced using hide and vegetable ${ }^{3}$-braided fibres. The ropes were used to affix objects to the handles (Fig. 5).

- Experimentation. Specific sectors ${ }^{4}$ within the Grotta della Monaca were chosen in order to conduct the experimental

\footnotetext{
$\overline{2}$ In this case, the wood could also be placed in water to increase its malleability.

${ }^{3}$ Ampelodesmos mauritanicus.

${ }^{4}$ The experimental extractive areas were selected to avoid damaging the ancient evidence.
}

tests. Two replicas were used to perform the exploitation of a deposit of soft/hydrated goethite located in the terminal area of the Sala dei Pipistrelli; two replicas were used for the exploitation of a vein of compact goethite within the Bivacco area; four replicas were used to excavate a calcite deposit and concretions layers in the Sala dei Pipistrelli; nine replicas were employed for extraction of copper carbonates on the walls of the Bivacco area; and two replicas were used for mixed activities on all minerals (hard and soft goethite; copper carbonate and calcite) (Fig. 6).

After the experiments, we have made the following observations:

1. The extraction of goethite (soft/hydrated and hard/compact) and calcite did not cause breakage or fractures on the experimental tools, which did not change their morphology.

2. During the extraction of the copper carbonates, the objects fractured, and several flakes were detached; thus, the functional areas were significantly reduced. We observed different patterns: longitudinal split fractures, oblique damage, and micro-flakes removals (Figs. 7, 8). 
Fig. 5 Experimental phases, manufacture of handles. a Type with flexible wood rolled around the groove. $\mathbf{b}$ Type of handle with $\mathrm{V}$-shaped termination. $\mathbf{c}-\mathbf{e}$ Finished tools
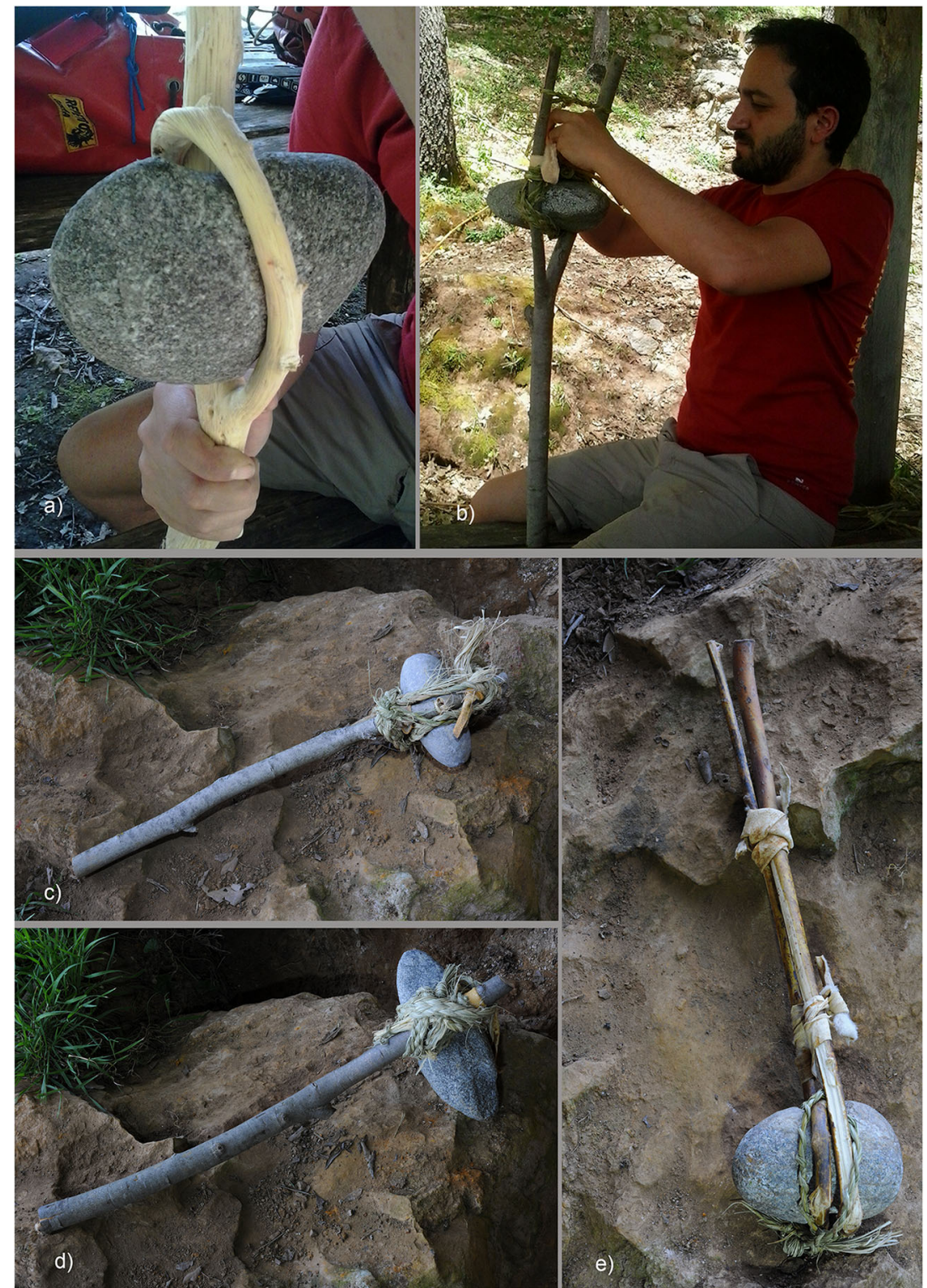

3. The extraction of copper minerals required a specific chaine opératoires. The heavier tools (such as hammers and picks, average weight $=1300 \mathrm{~g}$ ) were used to break up the large deposits of calcite concretion and unearth copper ore by removing the goethite layer. The smaller tools (hammer-axe or hammers on average $600 \mathrm{~g}$ ) were used directly on copper ore. Hammer-axes were particularly functional. Their cutting edge allowed them to penetrate the strata, facilitating the detachment of intact blocks without damaging the copper ore. Three hours of work were needed to extract approximately $1 \mathrm{~kg}$ of carbonates.

4. Each of the grooved stone tools manufactured was capable of extracting the hard (5 degrees on the Mohs scale) and soft goethite. One hour of work was required to obtain $6 \mathrm{~kg}$ of minerals.
5. V-shaped handles were not adequate for sustained tool use. During the experimentation, the tools required continuous adjustments. The most functional handles were those made out of willow wood, closely fitted around the groove.

6. The depth of the grooves or notches was a further factor determining the resistance of the handle.

\section{Results}

\section{Technological traces: a comparison between archaeological and experimental samples}

Technological traces were found preserved on the archaeological grooved stone tools from Grotta della Monaca. The initial 
blanks were constituted by natural cobbles, selected based on their shape. Macro-pits resulting from blank modification and from producing the grooves or notches are found extended to the whole body, or just to some areas of the objects, depending by the location of the convexities to be refined. Thus, no standard relationship between morphology of the blanks and related technological modifications are attested. Additionally, micro-traces connected to the adoption of abrasion technique were also found (both located in the grooves/notches and along the body of the object). Similar traces have been documented on the experimental samples, in particular those produced by using a sandstone slab (Fig. 9a, b). As result, the polishes are localised on the top of the levelled areas, characterised by oriented polishes and long striations with smooth texture and flat topography (Fig. 9c-f).

\section{Use-wear analysis of experimental samples}

\section{Macro-traces}

The macro-traces observed on the replicas consist generally in macro-pits (observed at $\times 10$ of magnification) and macrocracks on the grains' surface (observed at $\times 50-80$ of magnification). The morphology of macro-cracks differs according to the extracted mineral.
Fig. 6 Experimental extraction of several minerals at Grotta della Monaca. a, b Copper ore extraction. c Calcite excavation. d Vein of compact goethite. e Compact goethite extraction. $\mathbf{f}$ Soft/hydrated goethite extraction
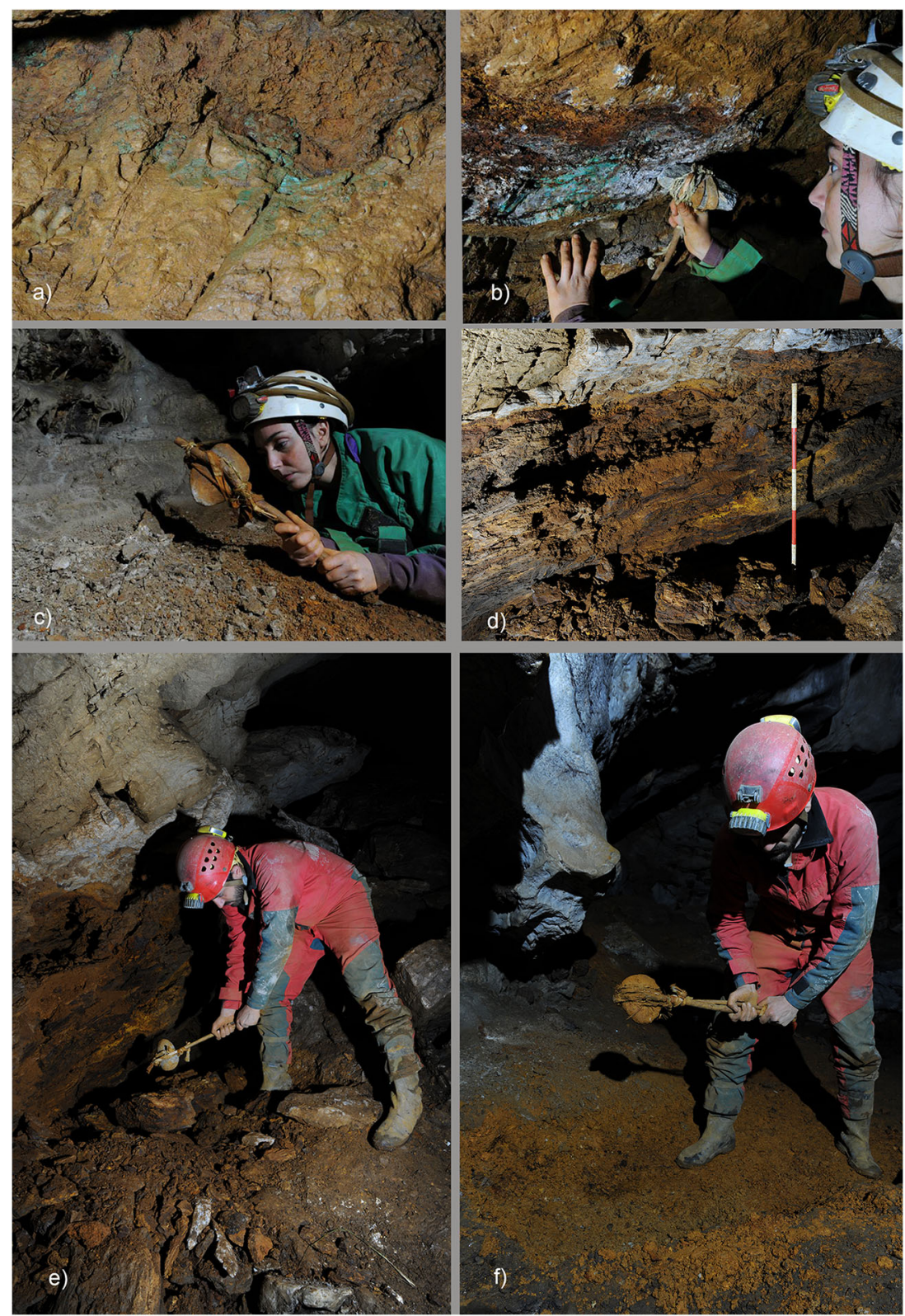
Fig. 7 Experimental replicas after use. (1) Pick used in calcite extraction; (2) pick used in copper ore extraction; (3) pick used in mixed minerals extraction; (4) hammer-axe used in copper ore extraction; (5-6) picks used in copper ore extraction; (7) hammer-axe used in soft/hydrate goethite extraction; (8) hammeraxe used in calcite extraction; (9) fractured hammer used in copper ore extraction; (10-13) fragment and flakes of hammers used in copper ore extraction; (14-15) hammers used in copper ore extraction; (16) hammer used in hard goethite extraction

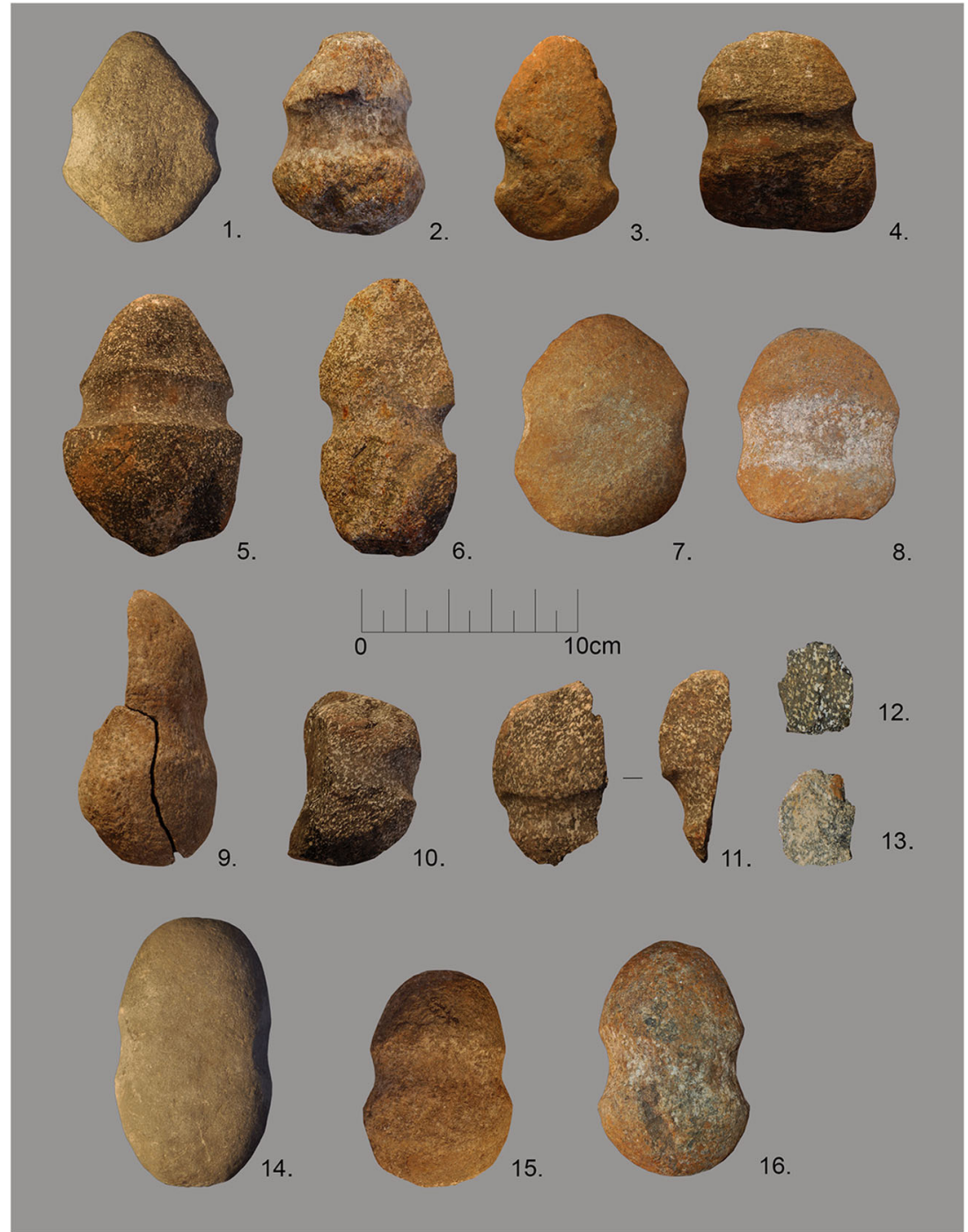

In the case of goethite, micro-fractures exhibit conchoidal morphology and the grains surface, observed at $\times 80$ of magnification, is characterised by a rough/glazing appearance (Fig. 10a, b, Table 4).

The functional area of the replica used in calcite extraction shows grains with tetrahedron and pointed morphology. The grains have a sheen (Fig. 10c, d, Table 4), probably due to contact with wet calcite. Often, calcite retains dripping water.

The extraction of copper carbonates produces deep macrofractures, with quadrangular detachments, giving the grain a characteristic "step" appearance (Fig. 10e, f, Table 4).

\section{Micro-traces}

The micro-traces observed on the experimental replicas are characteristic for each of the extracted minerals. The features used to describe the polishes are (a) the distribution which indicates the areas affected by the development of the micro-wear (magnification at $\times 50$ ); (b) the extension of the polishes on the top and/or bottom of the grains (magnification at $\times 100$ ); (c) the linkage represent the structures, intended as the degree of connection of the micro-wear (magnification at $\times 200$ ); and (d) the texture and topography which describe the surfaces of the polishes (magnification at $\times 200$ ) . Striations have also been described (i.e., they can be long, short, superficial and/or deep, chaotic, oriented, concentrated, sporadic, or polished (Table 5).

The polishes relating to the extraction of goethite are characterised by rough texture and granular topography, highly developed on the top and the bottom of the grains (Fig. 11ce, Table 6). The calcite use-wear is characterised by rough to smooth texture and domed topography. The sheen is high (Fig. 11g, h, Table 6). The polishes related to the extraction of copper carbonate (azurite and malachite) are associated 
Fig. 8 Post-use conditions of grooved stone tools with flexible wood rolled around the groove. a Pick used in copper ore extraction with reduced functional area. $\mathbf{b}$ Hammer used in copper ore extraction with multiple longitudinal fractures. c Pick use in mixed mineral extraction. $\mathbf{d}$ Hammer used in copper ore extraction with micro-fracture
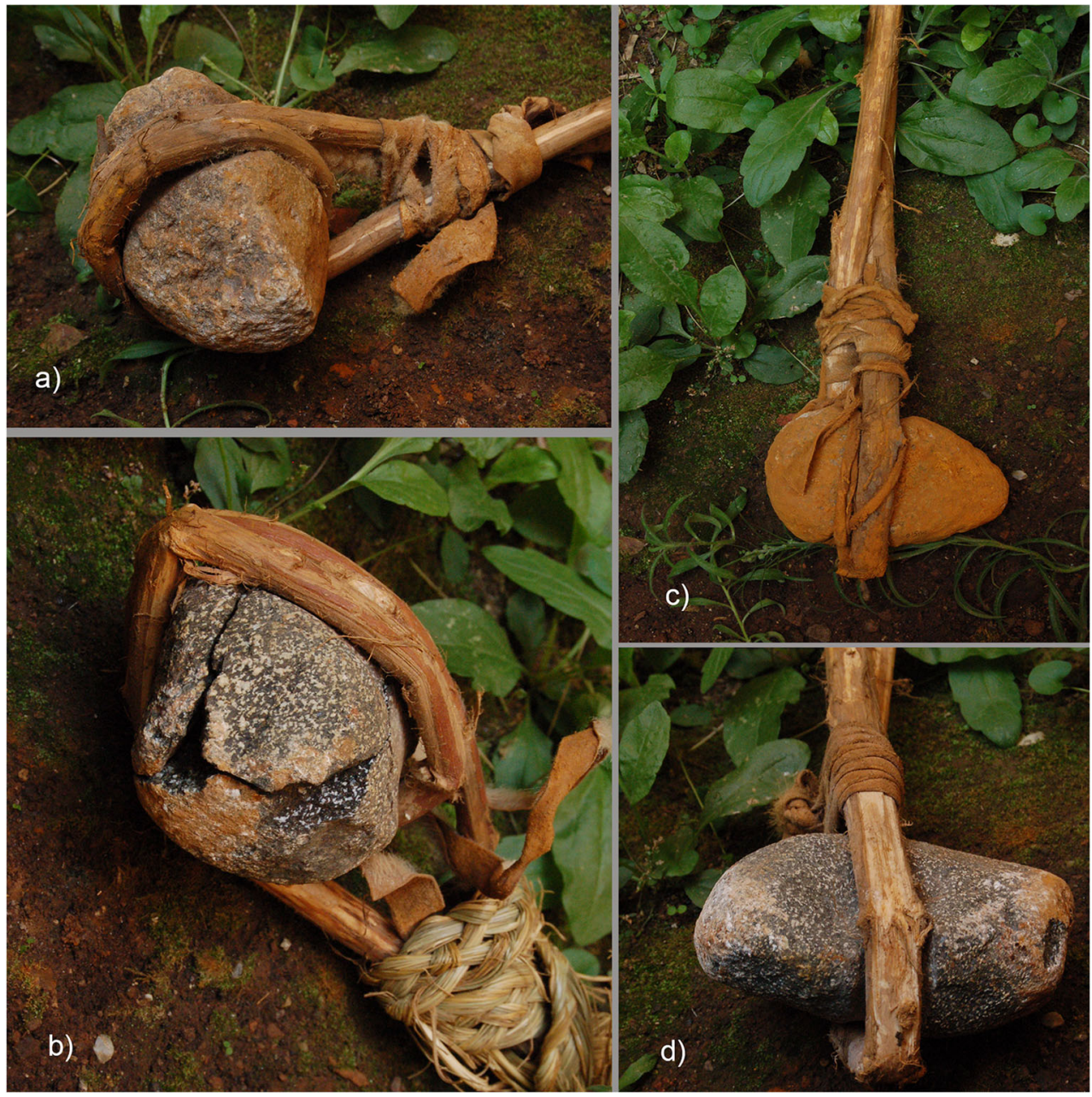

with long and oriented striations; the traces extended on the top of the grains with smooth texture and flat topography (Fig. 11a, b, Table 6). Finally, the polish distribution changes according to the mineral, its hardness, and hydration.

The replicas used to extract mixed minerals featured wear traces characterised by chaotic polishes, with rough and flat/ granular spots (Fig. 11f, Table 6).

\section{Use-wear analysis of archaeological samples}

The archaeological samples, twenty-five grooved stone tools, showed well-preserved use-wear traces (see supplementary materials Tab. 1). The lithic surfaces were partially affected by orange patinas due to contact with residue of goethite, a mineral found everywhere inside the cave, covering both the walls and the floor level of the mine. White patinas are instead related to the deposit of calcium carbonates. The traces observed on the functional areas of the samples allowed us to identify specific uses for the extractive tools found at Grotta della Monaca site.

The following aspects were identified:
(1) Fifteen samples present macro-pits and at $\times 85$ of magnification are visible grains with "step" morphology. At high magnification, long and oriented striations are observed on levelled areas and associated with polishes characterised by smooth texture and flat topography; the micro-traces extend to the top of the grains. The functional areas of these objects are often reduced by use. These traces can be interpreted as the result of the tools' contact with a copper mineral (Figs. 12, 13) and are present on 6 hammers (average weight of $874 \mathrm{~g}$ ), 6 hammer-axes (average weight of $1000 \mathrm{~g}$ ), 1 hammer-pick (weight $1641 \mathrm{~g}$ ), and 3 fragments/undefined tools;

(2) Five tools present rougher smooth polishes with domed topography and have a high sheen. The macro-topography appears sinuous. This trace finds a correlation with the calcite contact (Fig. 14) and is present on 3 picks (with an average weight of $2026 \mathrm{~g}$ ), 1 hammer (3112 g), and 1 hammer-axe (1044 g);

3) On 4 tools, there are traces characterised by chaotic polishes, with rough and flat/granular spots associated. These use-wear signatures have been interpreted as the result of contact with different minerals (copper ore/calcite or 
Fig. 9 Technological traces of abrasion stone vs stone. $\mathbf{a}, \mathbf{b}$ Experimental use-wear of abrasions, it is possible to observe levelled areas with oriented polishes and long striations. $\mathbf{c}-\mathbf{f}$ Archaeological use-wear
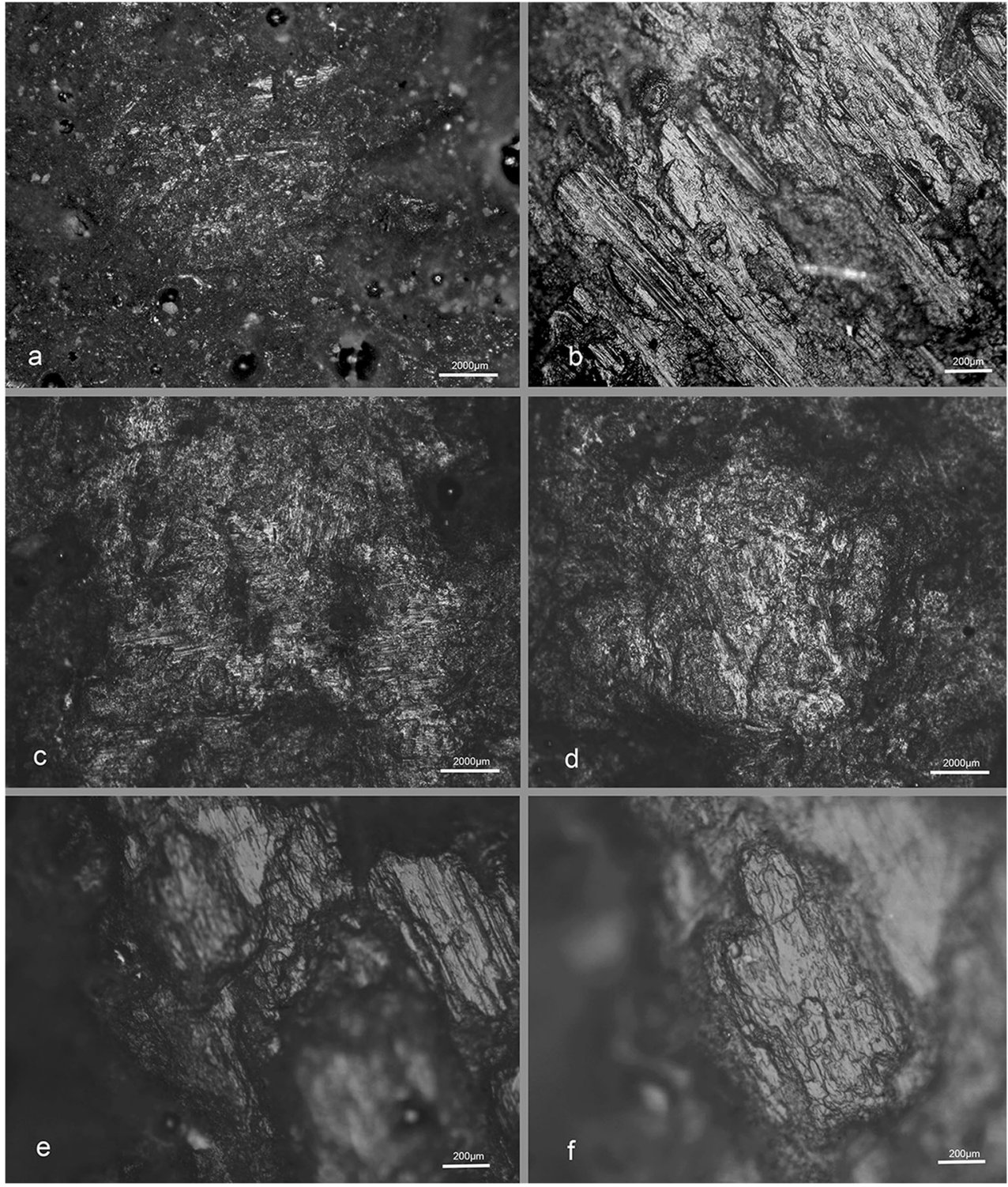

calcite/goethite) (Figs. 15, 16). Samples showing this type of traces are 1 pick (973 g), 1 hammer-axe (1584 g), and 3 hammers (with an average weight of $1348 \mathrm{~g}$ ).

\section{Discussion}

Through a combined low- and high-power approach, it was possible to define and interpret the precise function of the grooved stone tools found at the Grotta della Monaca mine. This method allowed us to identify specific surface grain morphologies related to the exploitation of different outcrops and type of minerals on the analysed tools. Additionally, the micro-polishes were found to be a discriminant feature to identify the extracted minerals.

The data obtained allowed us to reconstruct the chaîne opératoires of minerals exploitation at Grotta della Monaca, consisting (a) the adoption of heavy tools for the excavation of calcite planes, which sometimes are still very thick $(5-10 \mathrm{~cm})$ and which can cover the floors with mineralisations. The objects used for this kind of excavation were picks and hammeraxes of weights between 2 and $3 \mathrm{~kg}$. This extraction technique is partly confirmed by Larocca (2008), who identified many calcite fragments, stalagmites, or stalactites on the ground near the mining sectors, supporting this type of extraction technique; (b) tools employed in the excavation of mixed deposits, probably covering the copper ore outcrops, showing traces of 
Table 4 Macro use-wear observed on the experimental replicas. Graphic representation of grains morphology and modifications for each mineral extracted

\begin{tabular}{|l|l|}
\hline Mineral & Macro-traces \\
\hline Goethite & $\begin{array}{l}\text { Micro-fracture with conchoidal } \\
\text { morphology; grains with rough/glazing } \\
\text { appearance }\end{array}$ \\
\hline Calcite & $\begin{array}{l}\text { Micro-fractures with tetrahedron and } \\
\text { pointed morphology of the grains; sheen } \\
\text { appearance }\end{array}$ \\
\hline $\begin{array}{l}\text { Copper } \\
\text { carbonate }\end{array}$ & $\begin{array}{l}\text { Deep macro-fracture with "step" } \\
\text { appearance }\end{array}$ \\
\hline
\end{tabular}

mixed minerals (copper/calcite or calcite/goethite). No single trace indicating the exclusive excavation of goethite are attested in the analysed samples. The objects used in these activities are very variable, both in type (hammer-axes or hammers) and size; (c) finally, a higher number of grooved stone tools exhibiting wear traces due to the contact with copper ores and featuring a clear reduction of the functional areas. Use-wear resulting from copper minerals extraction is also present on a fragmentary object and its associated flakes from the Ramo delle Vaschette sector. This is the case of L15, which was discovered in association with flakes and charcoal samples dated to the late/final Neolithic. The objects used in the copper extraction were small hammers and hammer-axes, with an average weight between 800 and $1000 \mathrm{~g}$. As observed during the experimental tests, the axes-hammers are very useful objects in the excavation of copper deposits. Indeed, their trenchant is functional to penetrate the cracks in the rock and weaken the stratified levels in which the copper minerals emerge. These observations are confirmed by some objects analysed with preserved macro-residues of copper minerals on the grains within the functional areas. Also residues of goethite are present on entire collection and are often placed without a particular direction, generally around the tool's perimeter. This is likely due to the ubiquitous and massive presence of goethite, that are localised on the ground and on the walls of the cave. It is thus possible to assume that the goethite residues are due to the objects' contact with the ground, as documented in the experimental phase.

It is interesting to observe the different choices adopted by the prehistoric communities, related to the technology for the exploitation of goethite deposits and copper ores. In particular, the discovery of the mining sector Buca delle Impronte shows us that during the final Neolithic (c. 3780-3630 BC/3800$3640 \mathrm{BC})$, the goethite was extracted to a great extent with techniques that included the use of tools made from hard animal matter - proved by the presence of excavation imprints on hydrated goethite-according to a well-organised workspace and waste materials management (Levato and Larocca 2015). Instead, grooved stone tools were produced and used to exploit copper deposits during the late/final Neolithic (Cengia: 4170-3950 BC/4080-3940 BC; Ramo delle Vaschette: 4080-3920 BC/3950-3690 BC). A single sample the goat horn has been dated to the early Chalcolithic (3540-3660 BC). It is clear, therefore, that 
Fig. 10 Experimental macrotraces. a, b Use-wear of goethite, micro-fractures with conchoidal morphology and grains with rough/glazing appearance. $\mathbf{c}, \mathbf{d}$ Use-wear of calcite, microfractures with tetrahedron and pointed morphology of the grains. e, f Use-wear of copper ore, grains with "step" appearance
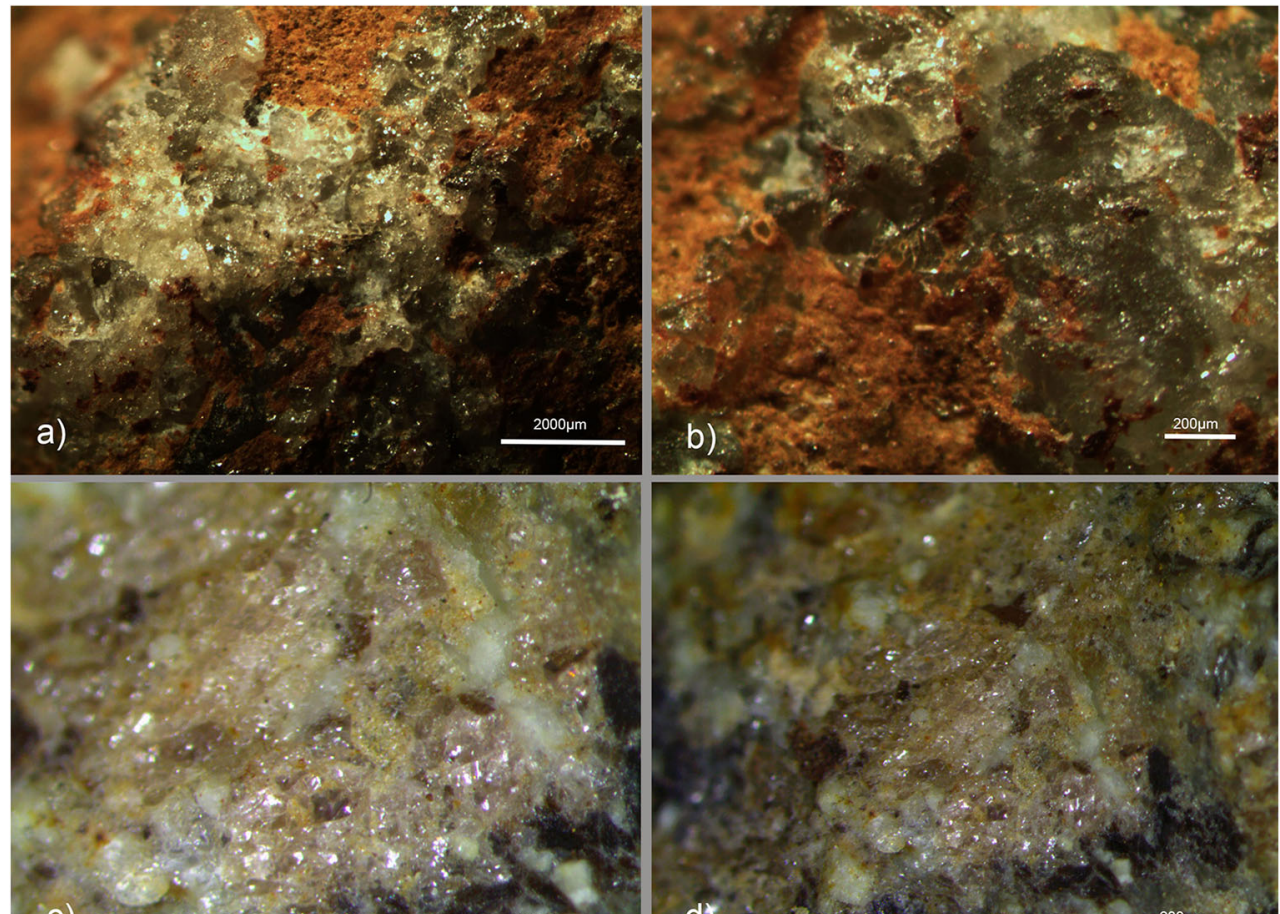

c)
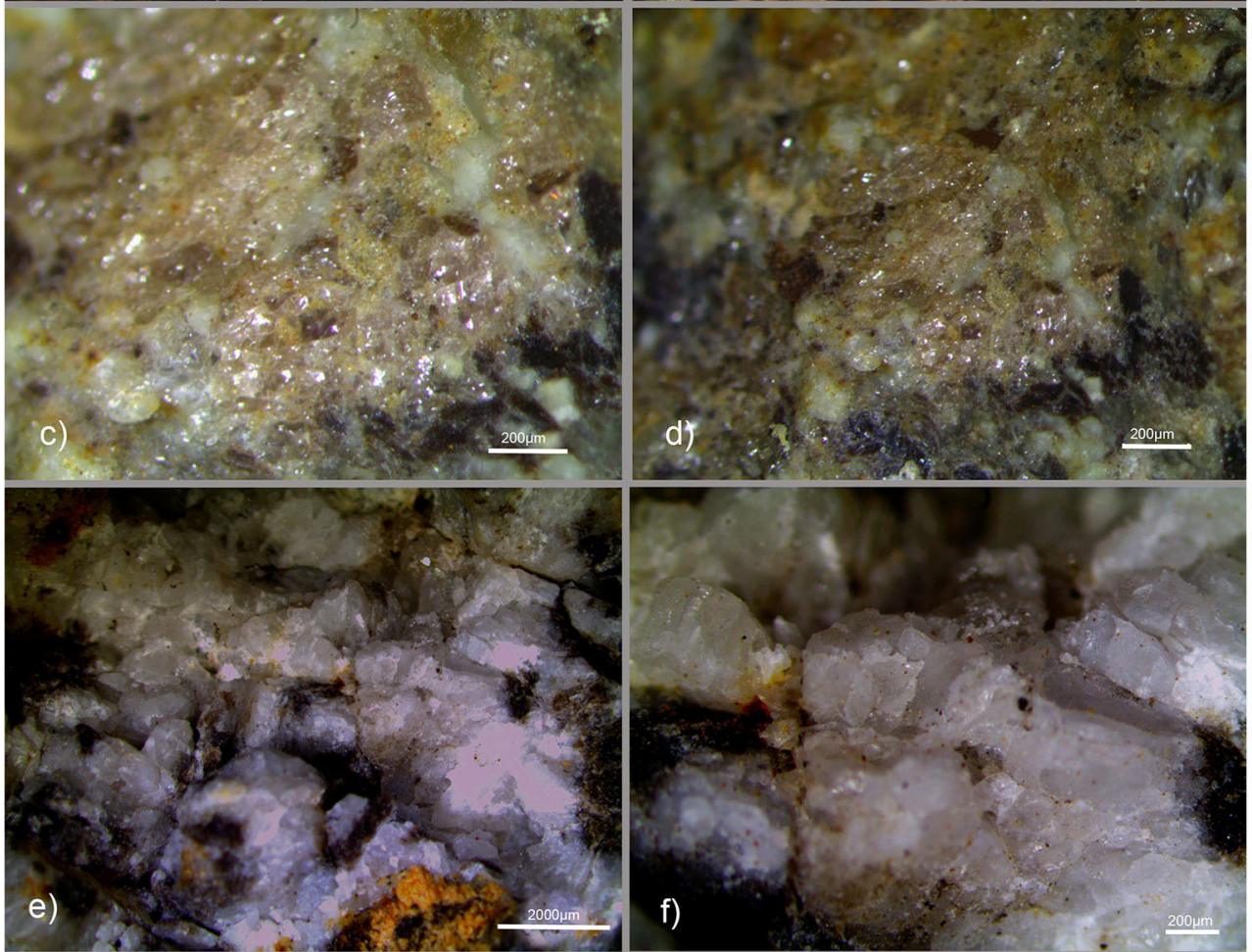

prehistoric miners approached two different outcrops - iron and copper ores-within the same mine using different excavation techniques and tools. This factor may depend on various aspects, such as functional choices, chronological differences or social aspects. However, the currently available data do not allow us to formulate a precise hypothesis, as there

Table 5 Parameters adopted in the description of the micro-traces

\begin{tabular}{|c|c|c|c|c|c|c|}
\hline \multicolumn{6}{|c|}{ Features of polishes } & \multirow{2}{*}{$\begin{array}{l}\text { References } \\
\text { Adams et al. } 2009\end{array}$} \\
\hline \multirow[t]{3}{*}{ Distribution } & Covered-separated & Covered-closed & Covered-connected & - & - & \\
\hline & Loose-separated & Loose-closed & Loos-connected & - & - & Adams et al. 2009 \\
\hline & Concentrated- separated & Concentrated-closed & Concentrated-connected & - & - & Adams et al. 2009 \\
\hline Extension & Top & Bottom & Top and bottom & - & - & Caricola 2017 \\
\hline Linkage & Open & Tight & Half tight & Reticulated & - & Lemorini 2000 \\
\hline Texture & Rough & Smooth & Rough to smooth & Grooved & - & Dubreuil et al. 2015; Van Gijn 2010 \\
\hline Topography & Flat & Domed & Granular & Pitted & Cratered & Van Gijn 2010 \\
\hline
\end{tabular}


Table 6 Micro use-wear observed on the experimental replicas. Features of use-wear related to different extracted minerals: goethite, calcite, and copper carbonate (azurite and malachite)

\begin{tabular}{|c|c|c|c|c|c|c|c|}
\hline Mineral & $\begin{array}{l}\text { Polish } \\
\text { distribution }\end{array}$ & $\begin{array}{l}\text { Polish } \\
\text { extension }\end{array}$ & $\begin{array}{l}\text { Polish } \\
\text { linkage }\end{array}$ & $\begin{array}{l}\text { Polish } \\
\text { texture }\end{array}$ & $\begin{array}{l}\text { Polish } \\
\text { topography }\end{array}$ & Sheen & Striations \\
\hline Goethite & Concentrated-connected & $\begin{array}{l}\text { Top and bottom of the } \\
\text { grains }\end{array}$ & $\begin{array}{l}\text { Half } \\
\text { tight }\end{array}$ & Rough & Granular & Medium & $\begin{array}{l}\text { Sporadic and not polished on } \\
\text { the bottom }\end{array}$ \\
\hline Calcite & Covered-connected & $\begin{array}{l}\text { Top and bottom of the } \\
\text { grains }\end{array}$ & Tight & $\begin{array}{l}\text { Rough tending } \\
\text { smooth }\end{array}$ & Domed & High & - \\
\hline $\begin{array}{l}\text { Copper } \\
\text { carbonate }\end{array}$ & Concentrated-closed & Top of the grains & Tight & Smooth & Flat & Medium & Long+oriented \\
\hline $\begin{array}{l}\text { Mixed } \\
\text { minerals }\end{array}$ & Covered-connected & $\begin{array}{l}\text { Top and bottom of the } \\
\text { grains }\end{array}$ & Tight & $\begin{array}{l}\text { Rough and } \\
\text { smooth }\end{array}$ & $\begin{array}{l}\text { Flat and } \\
\text { granular }\end{array}$ & Medium & $\begin{array}{l}\text { Sporadic+ } \\
\text { chaotic }\end{array}$ \\
\hline
\end{tabular}

are still many gaps regarding both the destination of the minerals and the identity of the miners in the region.

Currently, no traces of an initial treatment of copper ores have been found inside the mine. In fact, the ground stones and grinders/crushers discovered at the entrance to the mine, and probably connected with prehistoric exploitations, present traces of the treatment of goethite, as confirmed by the use-wear analysis conducted on these items (Caricola and Lemorini 2016; Breglia et al. 2016). The wide and well exposed Pregrotta area is thus interpreted as an atelier, a specific place for the first treatment of goethite, transported outside the cave in the form of powder (Caricola and Lemorini 2016). During the Middle Ages, the Pregrotta area was largely excavated by medieval miners and the result is a deposit of mixed materials, dating from the Neolithic to Middle Ages (Breglia et al. 2016). We hypothesise that grinding stone tools were connected to prehistoric miners since the few items found ( $n=11$ ground stones; $17=$ grinders/crushers) would be not able to satisfy the processing of huge quantities of goethite extracted during the Middle Ages. Moreover, during medieval and postmedieval times, the iron ore treatment - crushing, washing, and enrichment-was more complex. It is known from literature that these activities were carried out downstream using a water wheel (Šebesta 2000).

Iron ores are known to have different properties. For example, they can be used in the artistic and decorative fields (Levato 2013), thanks to their colouring quality (Salomon 2009). Among traditional societies, iron ore has several practical uses. It was likely used in body painting, hide processing, organic matter preservation, and medical remedy (Levato 2013: 20), perhaps as an ingredient in compound adhesives (Wadley 2005, 2010; Wolf et al. 2018). Among the Australian Aborigines, red ochre has a role in religious contexts, where it is used as a pigment and magical substance (Sagona 1994).
Copper ore extracted from Grotta della Monaca might have had another destination, currently unidentified. Even the use of this mineral is uncertain. We can, however, hypothesise different purposes, for example as a dye or employed in the production of metal tools. This latter is difficult to prove, due to the age of the context and the lack of compositional analyses of the isotopes of copper ores from Grotta della Monaca, that could allow us to investigate the provenance of metal tools found in Calabria.

The first evidence of smelting activities is attested in Italy during the late/final Neolithic (c. 4500-3800 BC and c. 38003600 BC) (Dolfini 2014; Dolfini et al. 2020). In particular, the oldest objects and smelting evidence are mostly present in northern Italy and are dated to the third quarter of the 5th millennium BC (Dolfini 2014; Mazzieri and Santo 2007; Visentini 2006). In Southern Italy, there is a little evidence related to Pizzica Pantanello, dated c. 3800-3550 BC (Giardino and D'Annibale 2014). As is the case at Grotta della Monaca, no traces of smelting inside or near the cave have been found. However, it is likely that after its extraction, the copper ore was not treated (i.e., ground) on-site but transported elsewhere.

Grotta della Monaca thus represents an exceptional mining context for several reasons. Firstly, the early date of the frequent uses is noteworthy. Secondly, it is not an open-air or subterranean artificial mine, featuring artificial wells and vertical tranches. The site is a karstic cave, used for millennia not only for extractive purposes but also for sepulchral and probably ritual ones (Larocca 2005). A very similar karstic cave is Grotta del Tesauro, located in the proximity of our site in the Upper Esaro Basin. Here, few grooved stone tools were found, most likely also related to the extraction of copper minerals during the prehistory (Garavelli et al. 2012; Caricola 2017). The data from Grotta del Tesauro and Grotta della Monaca highlight the systematic character of this search for copper ores through time implying an intense mining 
Fig. 11 Experimental microtraces. a, b Polishes of mineral copper ore. c-e Polishes of goethite. $\mathbf{f}$ Polishes of mixed mineral (copper ore, goethite, and calcite). g, h Polishes of calcite
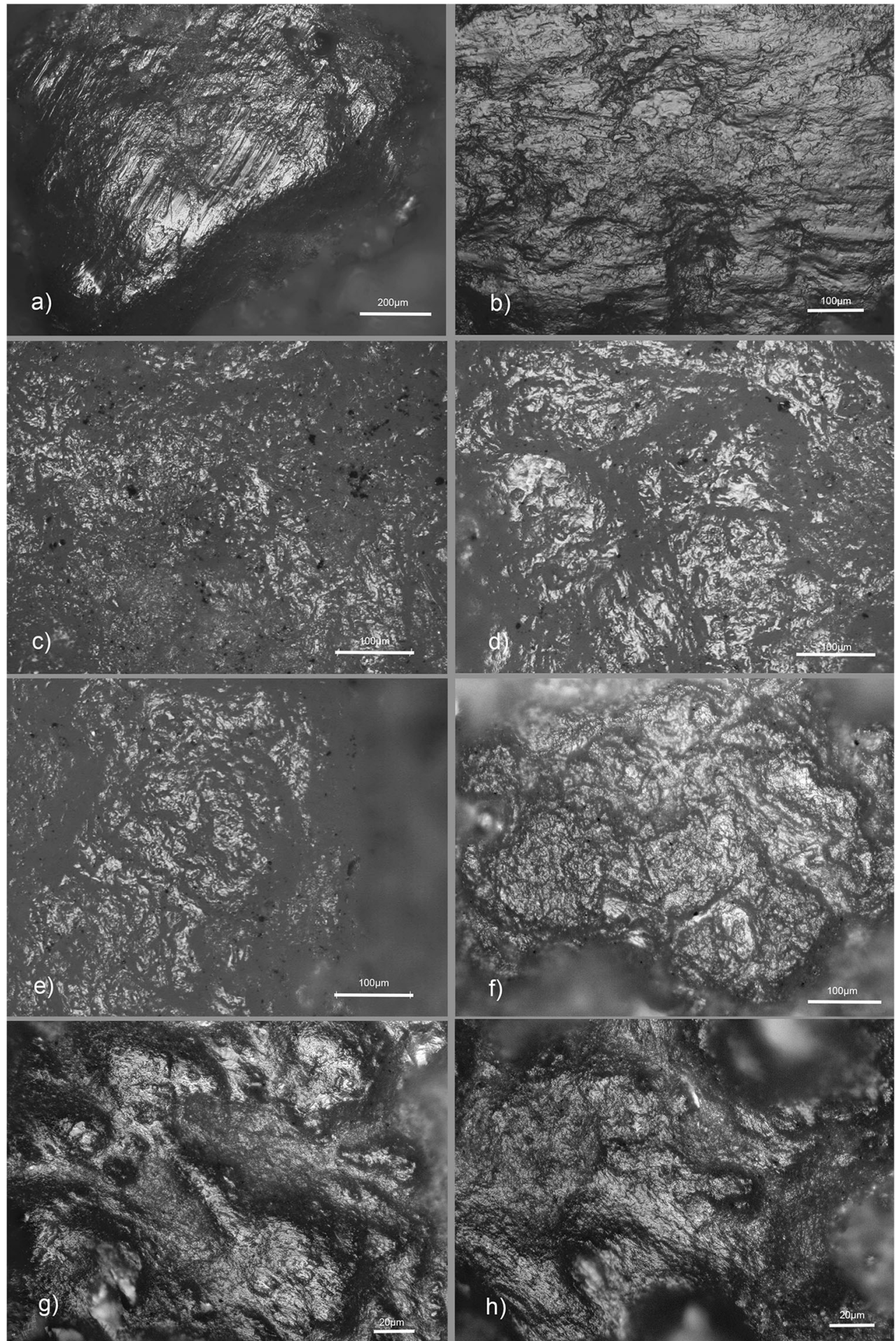

activity in the Calabrian Region, probably connected to emerging economic and social developments.

For the reasons listed above, there are substantial differences between the mines of Calabria, in particular
Grotta della Monaca, and the other Italian and European/ western Mediterranean mines. However, the grooved stone tools from the site certainly share a morphological correspondence with the tools found in the copper mines of 
Fig. 12 Archaeological sample n.L3 used in copper ore extraction. a, b Micro-polishes. c Detail of grains with "step" morphology. d Copper ore residues localised on functional area

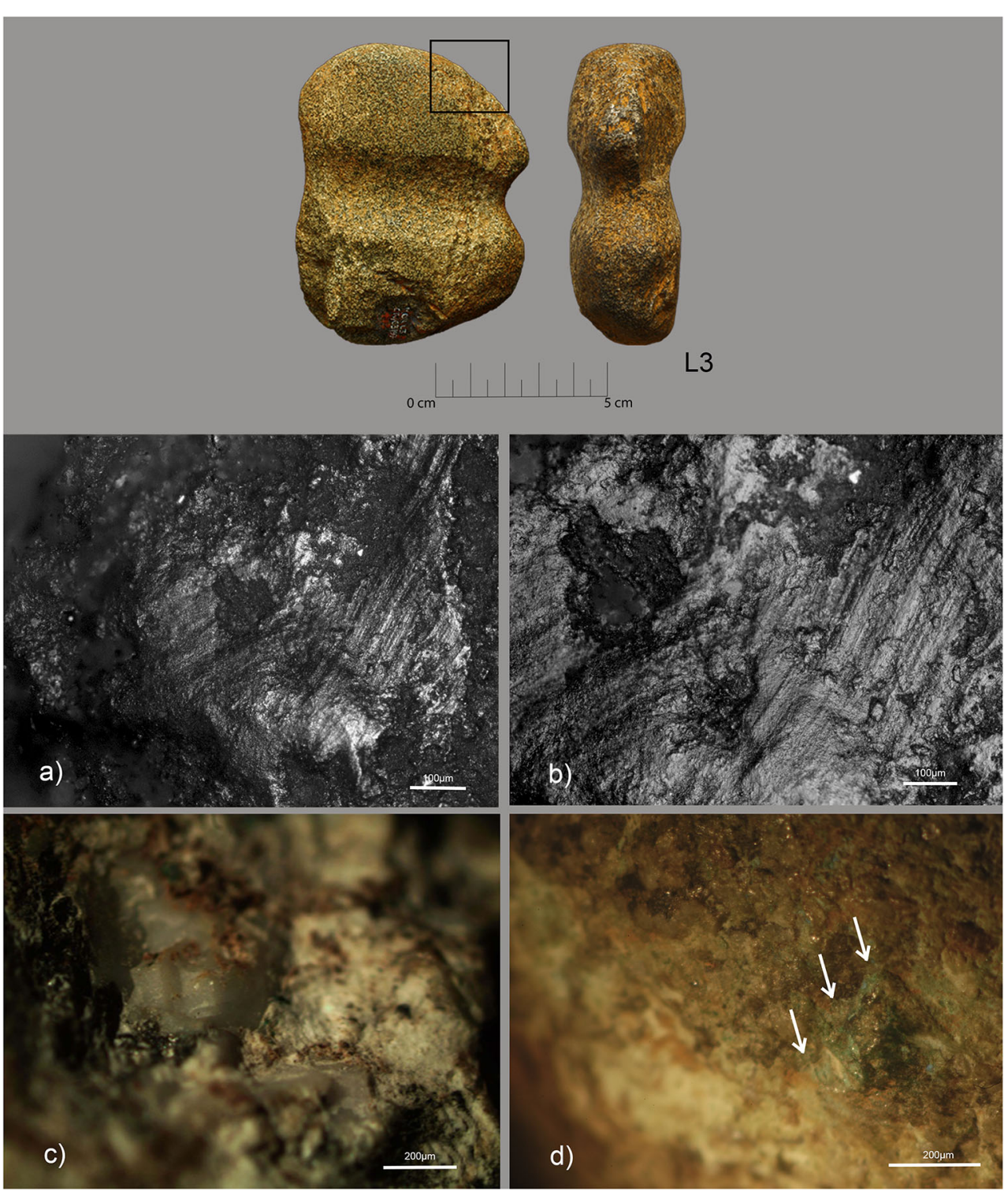

northern Italy, such as Libiola (3490-3120 BC) and Monte Loreto (3500-2500 BC) in Sestri Levante, Liguria (Maggi and Pearce 2005). Sub-spheroidal cobbles of basalt, dolerite, gabbro, sandstone, and diorite collected near the mine and modified for hafting with notching or single/double grooving (O'Brien 2014) have been found in this district. The predominant minerals are malachite, the main target in the Libiola mine, and chalcopyrite, probably extracted also thanks to the use of the fire setting (O'Brien 2014). This extraction technique seems not to have been used in Grotta della Monaca but is attested at other copper mines (as well as other materials; see Poggiali et al. 2017 for the cinnabar mine of Spaccasasso). The fire setting technique is documented in the Cabrières (Hérault) district in France, with dates that set the first mining between the late Neolithic/ early Chalcolithic (i.e., Pioch Farrus 448, 3100-2800 BC; Espérou et al. 1994). Quarzite mining tools (Ambert 2002) are very common in the Cabrières district, but differ greatly from those of Grotta della Monaca in terms of morphology and type of raw material. In addition, La Capitelle du Broum is used for the smelting and production of metal objects (Ambert et al. 2005). However, to date no smelting area has been found near Grotta della Monaca.

Alternative uses of copper ores, as well as the exploitation of malachite and azurite are attested in Serbia during the Middle Neolithic for bead production (Boric 2009). Nevertheless, only during the Late Neolithic is the exploitation of mines for metallurgical purposes recorded (e.g., 
Fig. 13 Archaeological sample n.L38 used in copper ore extraction. a, b Macro-traces, grains with "step" morphology. c, d Micro-polishes

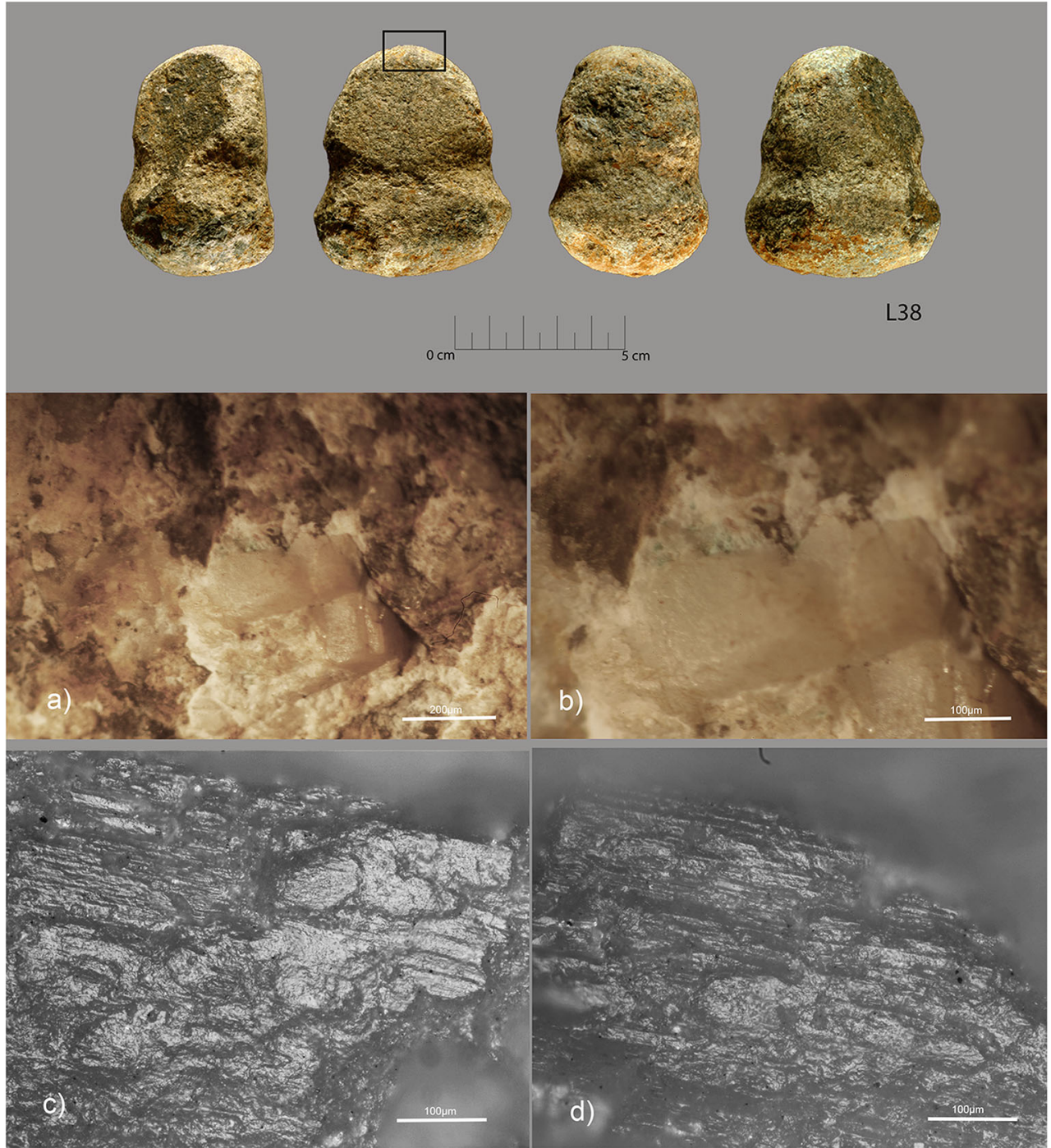

Rudna Glava, from 5400-5300 BC to $4700-4600 \mathrm{BC}$ ) (Jovanovic 1979).

Grooved stone tools are widespread not only in relation to copper mines, but there are examples of their use also in the exploitation of other minerals. A relevant case is represented by the Neolithic haematite mine in Bad Sulzburg (South West Germany), which was exploited around 5000 BC, and stone tools with notches and grooves were found in raw materials such as quartzites, granites, diorites, amphibolites, and various sedimentary rocks (Goldenberg et al. 2003).

The absence of a certain destination for the copper ore extracted at Grotta della Monaca does not allow us to formulate, at the present stage, hypotheses regarding the role of this mine during the late Neolithic/early Chalcolithic in Calabria, although it is clear that the miners went in search of copper outcrops, probably due to a specific demand of copper ores. The use-wear analysis of the macro-tools, to extract malachite and azurite, indicate that the miners had a good degree of specialisation since the early periods. This exploitation must have been motivated by a growing demand for resources on the part of prehistoric communities. This fits well with the European archaeological evidence referable to the Neolithic-Chalcolithic transition, when an intensification of mining activities and the circulation of products is testified (Müller 2013; Vandkilde 1996).

To date, Grotta della Monaca is the only known prehistoric mine in Calabria, but there is a high probability that new investigations in the region will reveal new ancient extractive sources or settlements associated with 
Fig. 14 Archaeological samples with traces of calcite. L8: a macro-traces; $\mathbf{b}$ micro-polishes. L18: c micro-polishes. L218: d micro-polishes

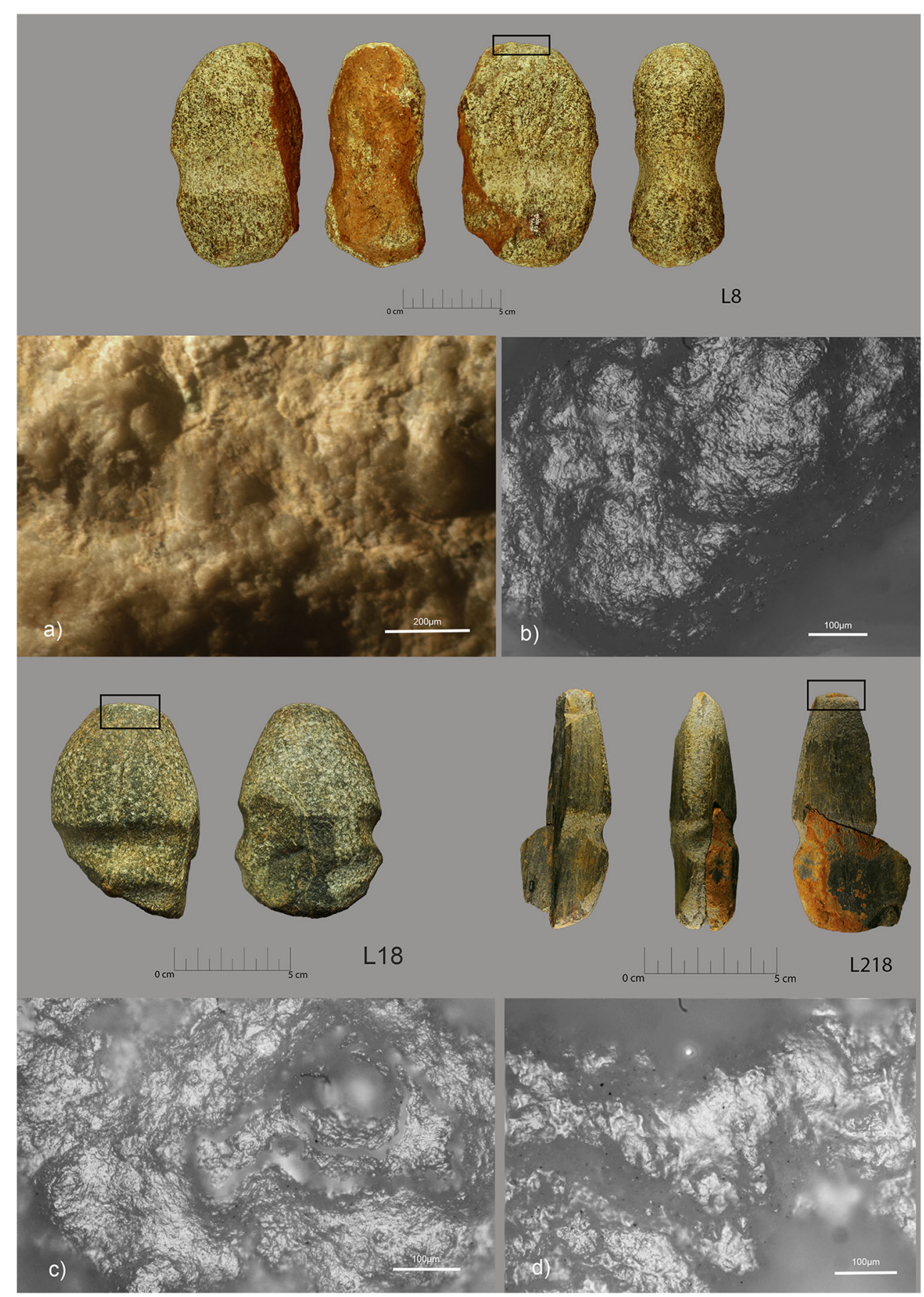

them. Currently, research on the Calabrian Region have made it possible to identify copper minerals outcrops in the north-western, central-eastern, and south-eastern parts of the region. It is unclear whether these outcrops were exploited during prehistoric times or not (Larocca and Breglia 2016). In the nearby of these latter, high concentrations of grooved stone tools have been found
(Larocca and Breglia 2016). The functional study of these tools will contribute to the comprehension of these aspects.

It cannot be excluded that this region could have played a role also in the distribution and circulation of minerals and other raw materials. The discovery of exotic objects such as Lipari's obsidian at Grotta della Monaca, starting from the 
Fig. 15 Archaeological sample n.L10 interpreted like a multiple contact with copper ore and calcite. a Macro-traces, overlapping pits. b, c Micropolishes. d Hafting micropolishes, contact with hide materials

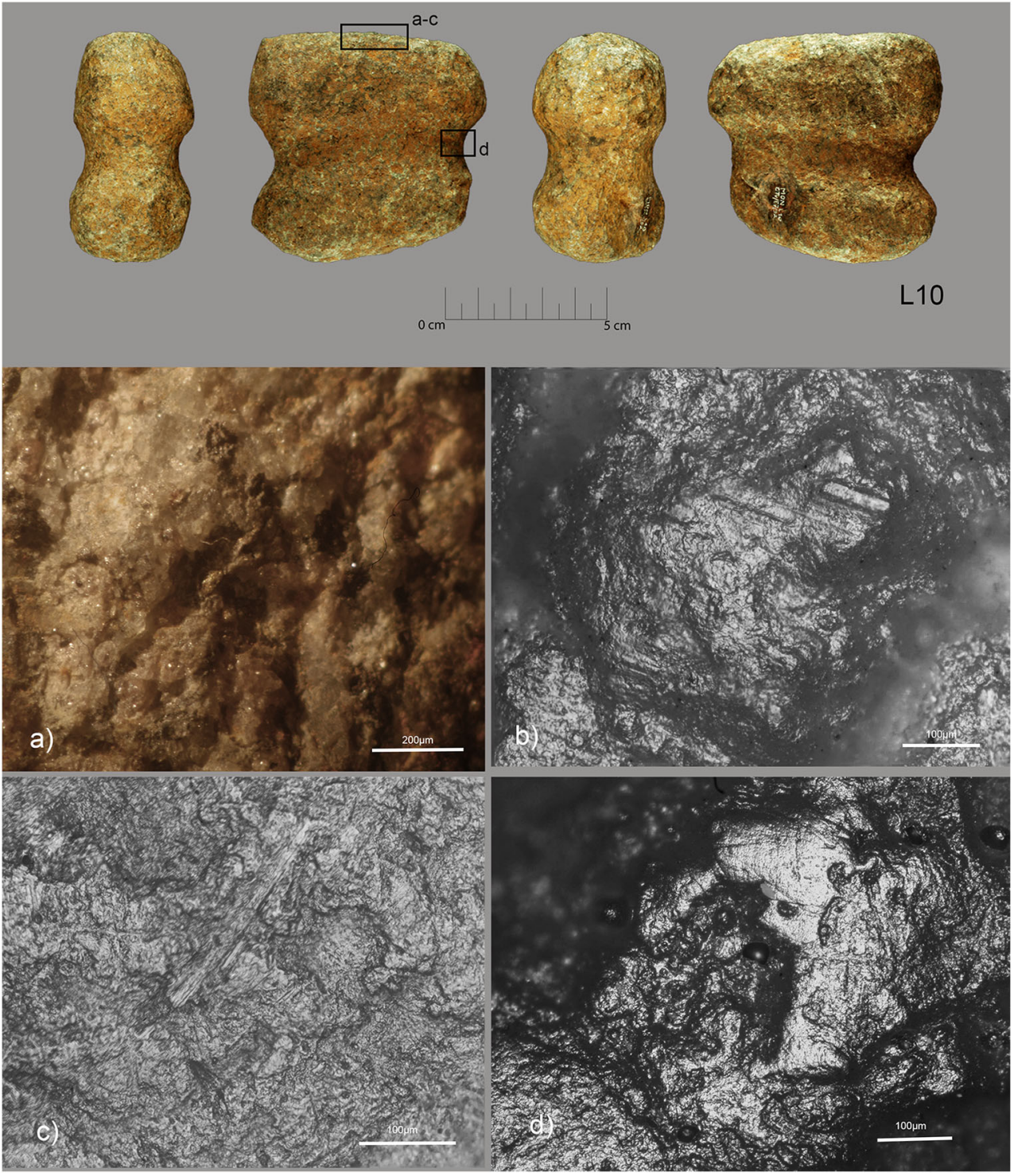

Neolithic, allows us to speculate that the area has been place of exchanges and contacts over the millennia. In addition, Grotta della Monaca is located along a strategic route in the Scalone Pass, which facilitates the transition from the inner mountainous territory to the coast.

\section{Conclusions}

During the late Neolithic and early Chalcolithic, Grotta della Monaca was the subject of minerals mining. The analysis of grooved artefacts confirms that they were related to the exploitation of copper ores. The miners used specialised technology and mining organisation, which demonstrates a high degree of knowledge of mineral stratifications and extractive methods. The discovery of Grotta del Tesauro, a small mine near Grotta della Monaca, where grooved stone tools with similar functional traces were found, indicates that groups of miners moved throughout the territory in search of copper ores. In this period, there was likely a specific need that motivated the mining activity. We have no evidence regarding eventual mineral processing workshops near the mine. We hope that future research in the area will shed light on the use of copper minerals extracted from Grotta della Monaca, as well as new radiocarbon dates could highlight more extraction phases, that those known to date at the site, in the sector certainly exploited for the extraction of copper minerals. 
Fig. 16 Archaeological sample, n. L22 interpreted like a multiple contact with goethite and calcite. a Rough micro-polishes. b Rough tending smooth/domed polishes

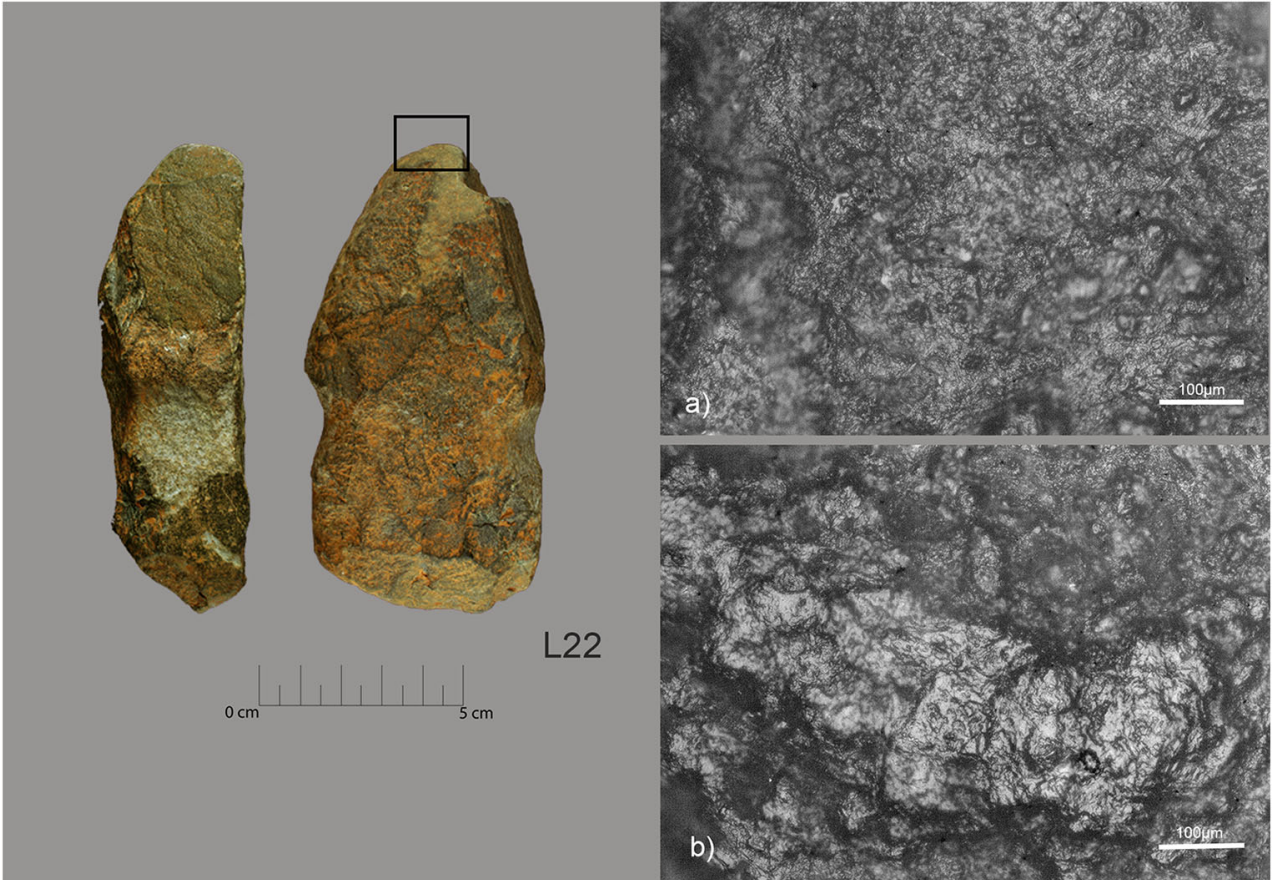

Acknowledgements Our deepest thanks go to Carmine Gallo for the collection of experimental stone and wood materials. We are also grateful to anonymous reviewers for their careful reading of the manuscript and constructive comments, which helped us to improve the final version of the article.

Authors' contributions All authors contributed to the study conception and design. Material preparation, data collection and analysis were performed by I.C. The experiments were performed by I.C. and F.B. The first draft of the manuscript was written by Isabella Caricola and all authors commented on previous versions of the manuscript. All authors read and approved the final manuscript.

Funding Not funding. This research is part of a $\mathrm{PhD}$ project conducted at the Sapienza University (Rome, Italy) in joint research with the Paris1Panthéon Sorbonne University (Paris, France).

Data availability No permits were required for the described study as the co-corresponding author, Dr. Felice Larocca, is Director of the excavation at the site of Grotta della Monaca and responsible for the scientific activity carried out on the archaeological findings recovered from the site. Dr. Larocca received permits for all aspects of this work from the archaeological authority.

\section{Compliance with ethical standards}

Conflicts of interest The authors declare that they have no conflict of interest.

Open Access This article is licensed under a Creative Commons Attribution 4.0 International License, which permits use, sharing, adaptation, distribution and reproduction in any medium or format, as long as you give appropriate credit to the original author(s) and the source, provide a link to the Creative Commons licence, and indicate if changes were made. The images or other third party material in this article are included in the article's Creative Commons licence, unless indicated otherwise in a credit line to the material. If material is not included in the article's Creative Commons licence and your intended use is not permitted by statutory regulation or exceeds the permitted use, you will need to obtain permission directly from the copyright holder. To view a copy of this licence, visit http://creativecommons.org/licenses/by/4.0/.

\section{References}

Acquafredda P, \& Piccarreta G (2005) Caratterizzazione petrografica dei manufatti litici, a cura di F. Larocca. La Miniera Pre-Protostorica Di Grotta Della Monaca (Sant'Agata Di Esaro-Cosenza), Volume Edito Dal Centro Regionale Di Speleologia "Enzo Dei Medici".

Acquafredda P, Larocca F, Muntoni IM, Pallara M (2016) SEM and XRF analyses as a tool to discriminate obsidian provenance from archaeological sites of central and southern Italy. International Obsidian Conference (Lipari, 1-3 giugno 2016)

Acquafredda P, Larocca F, Minelli A, Pallara M, Micheletti F (2020) Petroarcheometric analysis on obsidian artefacts found within some Neolithic-Eneolithic period caves of Southern Italy. Open Archaeol 6(1):107-123

Adams J, Delgado S, Dubreuil L, Hamon C, Plisson H, Risch R (2009) Functional analysis of macro-lithic artefacts. In: Sternke F, Costa L, Eigeland L (eds) Non-flint raw material use in prehistory: old prejudices and new directions. Proceedings of the XV. Congress of the U.I.S.P.P. Archaeopress, Oxford, pp 43-66

Ambert P (1995) Les mines préhistoriques de Cabrières (Hérault): quinze ans de recherches. État de la question Bulletin de La Société Préhistorique Française 92:499-508

Ambert P (1996) Cabrières-Hérault et le contexte régional du développement de la première métallurgie du cuivre en France (IIIeme millénaire av. J.-C.). Archéologie En Languedoc 20:1-3 
Ambert P (2002) Utilisation préhistorique de la technique miniere d'abattage au feu dans le district cuprifere de Cabrieres (Hérault). Comptes Rendus Palevol 1(8):711-716

Ambert P, Bouquet L, Guendon J-L, Mischka D (2005) La Capitelle du Broum (district minier de Cabrières-Péret, Hérault): établissement industriel de l'aurore de la métallurgie française (3100-2400 BC). In Ambert and Vacquer 2005:83-93

Angelini I, Artioli G, Pedrotti A, \& Tecchiati U (2013) La metallurgia dell'età del Rame dell'Italia settentrionale con particolare riferimento al Trentino e all'Alto Adige. Le risorse minerarie ei processi di produzione del metallo. L'età Del Rame: La Pianura Padana e Le Alpi al Tempo Di Otzi. Catalogo Della Mostra, Brescia: Compagnia Della Stampa Massetti, 101-116

Babel J (1986) The problems of the investigations of the flint mine at Krzemionki near Ostrowiec Swietokrzyski, woj Kielce and Tarnobrzeg voivodeships. 1, 27-42

Bánffy E (2015) The beginnings of salt exploitation in the Carpathian basin (6th-5th millennium BC). Documenta Praehistorica 42:197209

Binder D, Thomas Y, Beyries S, Bracco JP, Callou C, Cucchi T, Delhon C, Demeulenaere E, Dupont C, d'Errico F, De Garine E, Kuzucuoglu C, Langlais M, Manen C, Regert M, Maureille B, Vigne JL, \& De Garine E (2013) Systèmes culturels, stratégies et pratiques d'exploitation, de contrôle et de gestion des environnements. entre National de la Recherche scientifique (France), Prospective de l'Institut Ecologie \& Environnement du CNRS: compte-rendu des journées des 24 et 25 octobre 2012, Avignon, Centre national de la Recherche scientifique, pp.111-118, 2013, Les Cahiers Prospective

Boric D (2009) Absolute dating of metallurgical innovations in the Vinča culture of the Balkans, in: Kienlin, Tobias L. and Roberts, Ben W. eds. Metals and Societies: Studies in honour of Barbara S. Ottaway, Universitätsforschungen zur prähistorischen Archäologie, vol. 169. Bonn: Habelt, pp. 191-245

Bouquet L, Figueroa-Larre V, Laroche M, Guendon J-L, Ambert P (2006) Les Neuf-Bouches (district minier de Cabrières-Péret), la plus ancienne exploitation minière de cuivre de France: travaux récents, consequences. Bulletin de La Société Préhistorique Française 103:143-159

Breglia F, Caricola I, Larocca F (2016) Macrolithic tools for mining and primary processing of metal ores from the site of Grotta della Monaca (Calabria, Italy). J Lithic Stud 3(3):57-76. https://doi.org/ 10.2218/jls.v3i3.1651

Campana N, Maggi R, Pearce M, \& Ottomano C (2006) Quanto rame? stima della produzione mineraria del distretto di Sestri Levante fra IV e III millennio BC. Atti della XXXIX Riunione scientifica: materie prime e scambi nella preistoria italiana nel cinquantenario della fondazione dell'Istituto italiano di preistoria e protostoria, Firenze, 25-27 novembre 2004: vol. I-II-III, pp. 1339-1348

Campana N, Del Soldato M, Martino G (2014a) Gli affioramenti di rocce silicee in Liguria orientale e il loro sfruttamento durante la Preistoria. Archeologia Postmedievale 17:19-30

Campana N, Del Soldato M, Martino G, Negrino F (2014b) Gli affioramenti di rocce silicee in Liguria orientale e il loro sfruttamento durante la Preistoria. Archeologia Postmedievale 17: $19-30$

Campos AN, Herrero EA, Prieto MNF, Ortiz LP, Fernández FSR (2007) La más antigua minería metálica en tierras de León. In El hallazgo leonés de Valdevimbre y los depósitos del Bronce Final Atlántico en la Península Ibérica:220-237

Camprubí A, Melgarejo J-C, Proenza JA, Costa F, Bosch J, Estrada A, Andreiche VL (2003) Mining and geological knowledge during the Neolithic: a geological study on the variscite mines at Gavà, Catalonia. Episodes 26(4):295-301
Caricola I (2017) La funzione Dei macro-lithic tools e lo sfruttamento delle risorse minerarie durante la Preistoria recente nel Mediterraneo Occidentale. Tesi di PhD, Sapienza Università di Roma

Caricola I, \& Lemorini C (2017) Experimentation and traces analysis of macro-lithic tools: the case of Grotta della Monaca Cave (Sant'Agata di Esaro-Cosenza, Italy), in Playing with the time. Experimental archaeology and the study of the past, Eds. Alonso Alcalde, R., Baena, J., Canales Camarero, D., Universidad Autónoma de Madrid, Servicio de Publicaciones, pp. 107-112

Caricola I, Zupancich A, Moscone D, Mutri G, Falcucci A, Duches R, Peresani M, Cristiani E (2018) An integrated method for understanding the function of macro-lithic tools. Use wear, 3D and spatial analyses of an Early Upper Palaeolithic assemblage from North Eastern Italy. PloS One, 13(12). https://doi.org/10.1371/journal. pone. 0207773

Cavanna C, Pellegrini E (2007) 'La Buca di Spaccasasso: ricerche 2000 2004', in C Cavanna (ed), La Preistoria nelle Grotte del Parco Naturale della Maremma (Grosseto), 117-136

Cazzella A, Cultraro M, \& Recchia G (2011) Relazioni tra l'Italia centromeridionale, la Sicilia e l'area egeo-balcanica durante l'Eneolitico Relazioni tra l'Italia centro-meridionale, la Sicilia e l'area egeobalcanica durante l'Eneolitico, 157-164

Černych EN (1978) Aibunar a Balkan copper mine of the fourth millennium BC: (Investigations of the years 1971, 1972 and 1974). In Proceedings of the Prehistoric Society (Vol. 44, pp. 203-217). Cambridge University press

Charraud F, Fromont N, \& Ladjadj J (2014) Soumont-Saint-Quentin (Calvados)«La Mine». Nouveaux témoins d'extraction néolithique du silex bathonien. Revue Archéologique de l'Ouest, (31), 15-23

Collet H, Lavachery P, Woodbury M (2016) Raw material exploitation strategies on the flint mining site of Spiennes (Hainaut, Belgium). J Lithic Stud 3(2):1-36

Cortesogno L, De Pascale A, Gaggero L, Maggi R, \& Pearce M (2004) Strumenti litici per estrazione mineraria: il Caso di Monte Loreto (IV millennio BC). in D. Cocchi Genick (ed.), Atti della XXXIX Riunione Scientifica: materie prime e scambi nella preistoria italiana. Nel cinquantenario della fondazione dell'Istituto Italiano di Preistoria e Protostoria. Firenze, 25-27 novembre 2004, Vol. II: 683-695. Florence: Istituto Italiano di Preistoria e Protostoria

Cortina B (2011) Las minas prehistóricas del norte de España en el contexto de la paleominería del cobre del occidente de Europa. Presented at the Actas del quinto Congreso Internacional sobre Minería y Metalurgia Históricas en el SE Europeo (León, 2008): libro en homenaje a Claude Domergue.

Craddock B (1990) The experimental hafting of stone mining hammers. Early Mining in the British Isles 58

Crew P (1990). Firesetting experiment at Rhiw Goch, 1989. 1, 57

De Pascale A (2004) Hammerstones from early copper mines: sintesi dei ritrovamenti nell'Europa e nel Mediterraneo orientale e prime considerazioni sui mazzuoli di Monte Loreto (IV millennio BC Liguria). Rivista di Studi Liguri 69(2003):5-42

Delgado-Raack S, Gómez-Gras D (2017) Technological-functional study of the macrolithic artefacts from Solana del Bepo. Revista d'arqueologia de Ponent 2:45-63

Delgado-Raack S, Artigas NE, Risch R (2014) Mazas ocultas. Rastros de minería prehistórica en el Cerro Minado de Huercal-Overa (Almería). Cuadernos de Prehistoria y Arqueología de La Universidad de Granada 24:13-44

Di Lernia S, \& Galiberti A (1993) Archeologia mineraria della selce nella Preistoria. Definizioni, potenzialità e prospettive della ricerca (Vol. 36). All'Insegna del Giglio

Dimuccio, L., Garavelli, A., Pinto, D., Vurro, F., \& Larocca, F. (2005). Le risorse minerarie. La Miniera Pre-Protostorica Di Grotta Della Monaca (Sant'Agata Di Esaro-Cosenza). Centro Regionale Di Speleologia "Enzo de Medici", Roseto capo Spulico, Calabria, Italy $(37-41)$ 
Dimuccio LA, Rodrigues N, Larocca F, Pratas J, Amado AM, de Carvalho LAB (2017) Geochemical and mineralogical fingerprints to distinguish the exploited ferruginous mineralisations of Grotta della Monaca (Calabria, Italy). Spectrochim Acta A Mol Biomol Spectrosc 173:704-720

Dobosi VT (2006) Lovas (Hungary) ochre mine reconsidered. Der Anschnitt - Zeitschrift für Kunst und Kultur im Bergbau 19:29-36

Dolfini A (2014) Early metallurgy in the Central Mediterranean: goals for the next decade. Hist Metall 47:33-50

Dolfini A, Angelini I, Artioli G (2020) Copper to Tuscany-coals to Newcastle? The dynamics of metalwork exchange in early Italy. PLoS One 15(1):e0227259. https://doi.org/10.1371/journal.pone. 0227259

Dubreuil L, Savage D, Delgado-Raack S, Plisson H, Stephenson B, \& de la Torre I (2015) Current analytical frameworks for studies of usewear on ground stone tools. In Use-wear and residue analysis in archaeology (pp. 105-158). Springer, Cham.

Eerkens JW, Vaughn KJ, Grados ML (2009) Pre-Inca mining in the southern Nasca region, Peru. Antiquity 83(321):738-750

Espérou, J.-L., Ambert, P., Bourhis, J.-R., Roques, P., \& Gilot, E. (1994). La fosse chalcolithique Pioch-Farrus 448 (Cabrières, Hérault). Datation $14 \mathrm{C}$ et documents métallurgiques. Bulletin Du Musée d'Anthropologie Préhistorique de Monaco, (37), 53-62

Felder P (1981) Prehistoric Flint Mining at Rijckholt - St. Geertruid (NL), Grimes graves (England). Third International Symposium on Flint (Maastricht 24-27 May 1979), "Staringia", 6, 57-62

Gale D (1990) Prehistoric stone mining tools from Alderley Edge. Early Mining in the British Isles, 47-48

Galiberti A (2005) Defensola. Una Miniera Di Selce Di 7000 anni fa, Protagon Editori Toscani

Garavelli A, Pinto D, Vurro F, Mellini M, Viti C, Balić-Žunić T, Della Ventura G (2009) Yukonite from the Grotta Della Monaca cave, Sant'agata di Esaro, Italy: characterization and comparison with cotype material from the Daulton Mine, Yukon, Canada. Can Mineral 47(1):39-51

Garavelli A, Larocca F, Levato C, \& Pinto D (2012) Prehistoric mines of the upper Esaro Valley (Calabria. Italy). Presented at the 2nd Mining in European History Conference of the FZ HiMAT. The Impact of Historic and Prehistoric Mining Activities on the Environment and Societies in Europe (Innsbruck)

Genik DC (2008) Problematiche e prospettive della ricerca sull'età del rame in Italia in ricordo di Gianni Bailo Modesti. Problematiche e Prospettive Della Ricerca Sull'età Del Rame in Italia in Ricordo Di Gianni Bailo Modesti:13-21

Giardino C, D’Annibale C (2014) Pizzica Pantanello (Metaponto): la più antica testimonianza di attività metallurgiche dall'Italia meridionale. Annali Di Archeologia e Storia Antica 21:47-63

Goldenberg G, Maass A, Steffens G, \& Steuer H (2003) Hematite mining during the linear ceramics culture in the area of the Black Forest, South West Germany, in: T. Stöllner, G. Körlin, G. Stefens \& J. Cierny (eds), Man and Mining - Mensch und Bergbau, Der Anschnitt, 16: 179-186

Groman-Yaroslavski I, Rosenberg D, Yeshurun R, Kaufman D, Weinstein-Evron M (2016) The function of early Natufian grooved basalt artifacts from el-wad terrace, Mount Carmel, Israel: preliminary results of a use-wear analysis. J Lithic Stud 3(3):221-242

Guendon, J.L., Salazar, D., Figueroa-Larre, V., Salinas, H., Laroche, M., Ambert, P., Gruneisen, A. (2008). Déblais miniers et marteaux en Pierre du Néolithique final. Les mines de cuivre du plateau de Bellarade (district de Cabrières-Péret, Hérault, France), in Actes Rencontres Méridionales de Préhistoire Récente, 8, Marseille, 7-8 novembre, 403-412

Hamon, C. (2006). Broyage et abrasion au Néolitique ancien. Caractérisation technique et fonctionnelle des outillages en grès du Bassin parisien, BAR international Series 1551
Hamon C (2008) Functional analysis of stone grinding and polishing tools from the earliest Neolithic of north-western Europe. J Archaeol Sci 35(6):1502-1520. https://doi.org/10.1016/j.jas.2007. 10.017

Hamon C (2016) Salt mining tools and techniques from Duzdaği (Nakhchivan, Azerbaijan) in the 5th to 3rd millennium BC. J Field Archaeol 41(4):510-528. https://doi.org/10.1080/00934690.2016. 1201615

Harding A (2013) Salt in prehistoric Europe. Sidestone Press

Jackson MJ, Hitchiner MP (2013) High performance grinding and advanced cutting tools. Springer New York

Jovanović B (1979) The technology of primary copper mining in southeast. Europe. 45:103-110

Koukouli-Chrysanthaki C, \& Weisgerber G (1999) Prehistoric ochre mines on Thasos. 129-144

Larocca F (2005) La miniera pre-protostorica di Grotta della Monaca (Sant'Agata di Esaro-Cosenza). Roseto Centro Regionale di Speleologia "Enzo dei Medici"

Larocca F (2008) Grotta della Monaca (Sant'Agata di Esaro-Cosenza). Utensili e tecniche estrattive di età eneolitica per l'acquisizione di minerali di rame. Atti della XLIII Riunione Scientifica dell'Istituto Italiano di Preistoria e Protostoria (Bologna, 26-29 novembre 2008)

Larocca F (2010) Grooved stone tools from Grotta della Monaca and its mining district (Calabria, southern Italy), First International Meeting on on Prehispanic Mining in the Americas (Taltal - San Pedro de Atacama, Chile, 29 November - 4 December 2010)

Larocca F (2012) Grotta della Monaca (Calabria, Italia meridionale). Una miniera neolitica per l'estrazione dell'ocra. Rubricatum: Revista Del Museu de Gavà, (5), 249-256

Larocca F, Breglia F (2016) Grooved stone tools from Calabria region (Italy): archaeological evidence and research perspectives. J Lithic Stud 3(3):301-312

Laroche M, Ambert P, Guendon JL (coords.) (2011) Le village métallurgique chalcolithique de La Capitelle du Broum (Péret, Hérault). Bilan du troisième programme triennal 2009-2011, Dépôt SRA Languedoc-Roussillon, Montpellier, p. 207

Lemonnier P (1992) Elements for an anthropology of technology. University of Michigan Museum, Ann Arbor

Lemonnier P (2010) L'étude des systèmes techniques. Une urgence en technologie culturelle. Techniques \& Culture. Revue semestrielle d'anthropologie des techniques 54-55:46-67

Lemorini C (2000) Reconnaître des tactiques d'exploitation du milieu au Paléolithique Moyen: la contribution de l'analyse fonctionnelle: étude fonctionnelle des industries lithiques de Grotta Breuil (Latium, Italie) et de La Combette (Bonnieux, Vaucluse, France) (Vol. 858). British Archaeological Reports Limited

Levato C (2013) Iron oxides prehistoric mines a European overview. Anthropologica et Præhistorica, 126/2015 (2016): 9-23

Levato C, Larocca F (2015) The prehistoric iron mine of Grotta della Monaca (Calabria, Italy). Anthropologica et Præhistorica:125-2014

Lewis A (1990) Fire-setting experiments on the Great Orme, 1989. 1, 5556

Maggi R, Del Lucchese A (1988) Aspects of the Copper Age in Liguria. Rassegna di Archeologia 7:331-338

Maggi R, Pearce M (2005) Mid fourth-millennium copper mining in Liguria, north-west Italy: the earliest known copper mines in Western Europe. Antiquity 79(303):66-77

Maggi R \& Pearce M (2014) Cronologia mineraria in Liguria. In D. Cocchi Genik (eds.), Cronologia assoluta e relativa dell'età del Rame in Italia, Atti del I Incontro di Studi (Università di Verona, 23 giugno 2013), 5-15

Mazzieri P, Santo ND (2007) Il sito del Neolitico recente di Botteghino (Parma). Il Sito Del Neolitico Recente Di Botteghino (Parma):113138 
Migal W (1997) Reconstruction of the flint extraction system in Krzemionki. 315-325

Müller J (2013) Missed innovation: the earliest copper daggers in northern Central Europe and Southern Scandinavia. In S. Bergerbrant and S.Sabatini (eds.), Counterpoint: Essays in Archaeology and Heritage Studies in Honour of Professor Kristian Kristiansen, pp. 443-448. Oxford: Archaeopress

Negrino F, Starnini E (2010) Dinamiche di sfruttamento e circolazione delle materie prime silicee per l'industria litica scheggiata in Liguria tra Paleolitico inferiore ed Età del Rame. Atti Della Tavola Rotonda, Genova, pp 21-34

O’Brien W (1997) Mount Gabriel and metal sourcing in the Bronze Age. J Hist Metall 31(1):8-11

O'Brien W (2014) Prehistoric copper mining in Europe: 5500-500 BC. OUP Oxford

Olivier L, Kovacik J (2006) The Briquetage de la Seille (Lorraine, France): proto-industrial salt production in the European Iron age. Antiquity 80(309):558-566. https://doi.org/10.1017/ S0003598X00094035

Pacciarelli M, Talamo P (2011) Sull'articolazione dell'età del Rame nell'Italia meridionale tirrenica. Sull'articolazione dell'età del Rame nell'Italia meridionale tirrenica:87-94

Pfaffenberger B (1998) Mining communities, chaînes opératoires and sociotechnical systems. Social Approaches to an Industrial Past, The Archaeology and Anthropology of Mining, pp 291-300

Poggiali F, Buonincontri MP, D'Auria A, Volante N, Di Pasquale G (2017) Wood selection for firesetting: first data from the Neolithic cinnabar mine of Spaccasasso (South Tuscany, Italy). Quat Int 458: 134-140. https://doi.org/10.1016/j.quaint.2017.06.028

Preuschen E (1973) Estrazione mineraria dell'età del Bronzo nel Trentino. Preistoria Alpina 9:113-150

Quarta G, Larocca F, D’Elia M, Gaballo V, Macchia M, Palestra G, Calcagnile L (2013) Radiocarbon dating the exploitation phases of the Grotta della Monaca cave in Calabria, Southern Italy: a prehistoric mine for the extraction of iron and copper. Radiocarbon 55(3): $1246-1251$

Rafel N, Ruiz IM, Soriano I, Delgado-Raack S (2016) L'activité minière préhistorique dans le Nord-Est de la péninsule Ibérique: Étude sur la Coveta de l'Heura et l'exploitation du cuivre à la Solana del Bepo (Tarragone, Espagne). Bulletin de La Société Préhistorique Française 113(1):95-129

Rostan P, \& Thirault E (2016) L'usage du quartz hyalin dans les Alpes Durant la Préhistoire: une vue d'ensemble. Nouvelles données en Oisans (Isère et Hautes-Alpes). In A. Tomasso, D. Binder, D. Martino, G. Porraz, G. Simon, \& N. Naudinot (eds.), Ressources Lithiques, Production et Transferts entre Alpes et Méditerranée, Acte de la Séance de la Société Préhistorique Française, Nice, 2829 Mars 2013, 97-136

Sagona AG (1994) Bruising the red earth: ochre mining and ritual in Aboriginal Tasmania. Melbourne University Press
Salerno A, Vanzetti A (2004) L'Eneolitico e il Bronzo antico in Calabria. Atti XXXVII Riunione Scientifica IIPP I:207-234

Salomon H (2009) Les matières colorantes au début du Paléolithique supérieur. Sources, Transformations et Fonctions. PhD Dissertation at the Université Bordeaux 1.

Scaramucci S, Volpi V, Costantini A, Giamello M, Donati A, Aranguren B, Moroni A (2016) New challenges in the study of lithic raw materials in central Italy at the dawn of metal working societies: La Pietra and other radiolarite quarry-workshops in Tuscany. J Lithic Stud 3(2)

Šebesta G (2000) La via del rame. Museo degli Usi e Costumi della Gente Trentina, S. Michele all'Adige

Stöllner T (2003) Mining and economy: a discussion of spatial organisations and structures of early raw material exploitation. In: Stöllner T, Körlin G, Steffens G, Cierny J, editors. Man and Mining-Mensch und Bergbau: Studies in Honour of Gerd Weisgerber. Der Anschnitt, Beiheft 16. Bochum: Deutsches Bergbau-Museum; 2003. p. 415-446

Tarriño A, Elorrieta I, García-Rojas M, Orue I, Sánchez A (2014) Neolithic flint mines of Treviño (Basque-Cantabrian Basin, Western Pyrenees, Spain). J Lithic Stud 1(2):129-147

Timberlake S (1990) Firesetting and primitive mining experiment, Cwmystwyth, 1989. 1, 53-54

Van Gijn A (2010) Flint in focus: lithic biographies in the Neolithic and Bronze Age. Sidestone Press, Leiden

Vandkilde H (1996) From stone to bronze: the metalwork of the Late Neolithic and earliest Bronze Age in Denmark. Aarhus University Press, Aarhus

Visentini P (2006) Aspetti cronologici e culturali della fine del Neolitico nell'Italia nord-orientale, in Preistoria dell'Italia settentrionale. Studi in ricordo di Bernardino Bagolini (eds. A. Pessina and P. Visentini), 225-41, Proceedings of the International Congress, Udine, 23-24 September 2005

Wadley L (2005) Putting ochre to the test: replication studies of adhesives that may have been used for hafting tools in the Middle Stone Age. J Hum Evol 49(5):587-601. https://doi.org/10.1016/j.jhevol.2005.06. 007

Wadley L (2010) Compound-adhesive manufacture as a behavioral proxy for complex cognition in the middle stone age. Curr Anthropol 51(S1):S111-S119. https://doi.org/10.1086/649836

Wolf S, Conard NJ, Floss H, Dapschauskas R, Velliky E, Kandel AW (2018) The use of ochre and painting during the Upper Paleolithic of the Swabian Jura in the context of the development of ochre use in Africa and Europe. Open Archaeol 4(1):185-205

Publisher's note Springer Nature remains neutral with regard to jurisdictional claims in published maps and institutional affiliations. 